\title{
南西諸島，喜界島における後期更新世・完新世の砂丘の形成
}

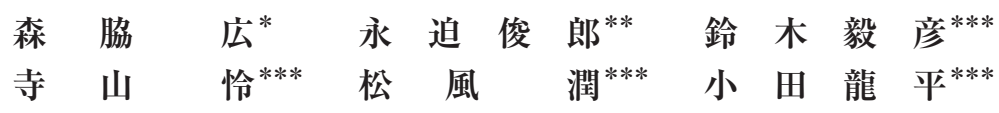

\section{The Formation of Late Pleistocene and Holocene Sand Dunes on Kikaijima Island, Nansei Islands}

\author{
Hiroshi MORIWAKI*, Toshiro NAGASAKO ${ }^{* *}$, Takehiko SUZUKI ${ }^{* * *}$,
} Satoshi TERAYAMA***, Jun MATSUKAZE ${ }^{* * *}$ and Ryuhei ODA***

[Received 21 December, 2020; Accepted 20 April, 2021]

\begin{abstract}
Coastal sand dunes dating to the latter part of the late Pleistocene were constructed at substantially lower sea levels on Kikaijima Island. They are preserved because of large-magnitude uplifts ascertained from occurrences of outstanding late Pleistocene and Holocene coral terraces. In addition, because Holocene sand dunes occur close to those of Marine Oxygen Isotope Stage 3 (MIS 3), the island is ideal for examining the environments of the formation of sand dunes, which were constructed under different climatic and sea-level conditions. Distributional and depositional features of sand dunes are clarified, and their chronology is constructed on the basis of tephrochronology, ${ }^{14} \mathrm{C}$ dating, and chronological relationships of the sand dunes with marine terraces of known age. The environments of sand-dune formation on Kikaijima are examined in relation to climatic and sea-level records within regional and global contexts. Nine tephra layers are recognized. These include two widespread tephras, Kikai-Akahoya tephra (K-Ah) and AiraTn tephra (AT). The other seven tephras, consisting of fine ash layers, are newly recognized and named Kikaijima-1 tephra (Kj-1) to Kikaijima-7 tephra (Kj-7), of which the upper six, lying between K-Ah and AT, are aged from 13,000 to 30,000 cal BP. Holocene sand dunes began to form at c. 8,000 cal $\mathrm{BP}$ before the culmination of maximum Holocene sea-level rise. This is earlier than dune formation on other coasts of the Japanese Islands, where formation was generally after the culmination of maximum Holocene sea-level rise. The earlier formation on Kikaijima Island is probably due to coastal emergence caused by the conspicuous uplifts of Kikaijima and the high production of calcareous beach sands sourced from coral and foraminiferal and other materials. Late Pleistocene sand dunes, predominantly distributed at the southwestern part of Kikaijima Island, were formed in MIS 3. These dunes consist of longitudinal and parallel dunes. The largest longitudinal dunes on the lowest MIS 3 terraces, at the northern area of the southwestern part of Kikaijima Island, were formed in late MIS 3, c. 40 to $32 \mathrm{ka}$, while small and parallel sand dunes on the upper MIS 3 terraces were formed in early MIS 3. The occurrence and chronology of the Holocene and late Pleistocene sand dunes suggest that their formation on Kikaijima

\footnotetext{
* 鹿児島大学名誉教授

** 鹿児島大学学術研究院法文教育学域教育学系

*** 東京都立大学都市環境学部

* Professor Emeritus, Kagoshima University, Kagoshima, 890-8580, Japan

** Research Field in Education, Education, Law, Economics and the Humanities Area, Kagoshima University, Kagoshima, 890-0065, Japan

*** Graduate School of Urban Environmental Sciences, Tokyo Metropolitan University, Hachioji, 192-0397, Japan
} 
Island is mainly related to the occurrence of coastal sandy beaches during sea-level high stands. Although Holocene sand dunes are related to Holocene high stand, those of MIS 3 are related to high stands during cycles of sea-level fluctuations in MIS 3. The longitudinal landform of the sand dunes recognized in the late MIS 3 suggests that the prevailing winds in MIS 3 were stronger than in the Holocene. This study provides critical data for constructing a chronological framework that integrates various aspects of palaeoenvironments, as well as human interactions and responses in southern Kyushu.

Key words : sand dune, tephra, Holocene, late Pleistocene (MIS 3), Kikaijima, Nansei Islands キーワード : 砂丘, テフラ, 完新世, MIS 3, 喜界島, 南西諸島

\section{I. はじめに}

喜界島は，南西諸島の北部，奄美大島の東方， 琉球海溝にもっとも近い外弧隆起帯にある周囲 $37 \mathrm{~km}$ の島である。本島は，全島が第四紀後期 のサンゴ礁段丘からなり, 西太平洋海域では, 奄 美大島・宝島・小宝島とともに，サンゴ礁段丘最 北域となっている（図 1 ; 町田ほか, 2001）。更 新世のサンゴ礁段丘は，第三紀鮮新世・第四紀前 期更新世の泥質岩石からなる島尻層群や中期更新 世のサンゴ石灰岩を基盤として複数の段丘面から なる。それらは多くのウラン系列年代測定がなさ れ，最終間水期以降の形成であることが明らかに されている (Konishi et al., 1974; 大村, 1988 ほ か)。これらの年代をもとに段丘面は上位から $\mathrm{A}$ 〜 F 面に区分されている（太田・大村, 2000) (図 1 )。海洋酸素同位体ステージ $5 \mathrm{e}$ (MIS 5e) の $\mathrm{A}$ 面（百之台面）は，海抜高度およそ $200 \mathrm{~m}$ にあり，日本列島では後期更新世以降もっとも 隆起量の大きい場所となっている（太田ほか, 2010)。そのため, 最終水期の亜間水期 MIS 3 の サンゴ礁段丘面である $\mathrm{D}, \mathrm{E} ， \mathrm{~F}$ 面が現在の陸上 に存在しているという点で, 日本でもきわめて希 な地域となっている（太田・大村, 2000, 稲垣ほか, 2005)。 D， E， F 面は海抜高度 90 ～ $15 \mathrm{~m}$ にあ り，喜界島上位の $\mathrm{A}, \mathrm{B}, \mathrm{C}$ 面の周囲にもっとも 広く分布する。これらの更新世段丘を取り巻い て, 最高高度 $10 \mathrm{~m}$ 前後の完新世サンゴ礁段丘が 連続的に発達し，段丘面の詳しい年代や編年，海
面変化が論じられてきた（中田ほか, 1978; 太田 ほか, 1978 ほか)。

こうした更新世・完新世の段丘面上には砂丘が 分布する（図 1，2）。Hanzawa（1935）が喜界 島地史上最新の層位に位置づけられる砂丘が発達 することを指摘して以後，とくに広く分布する喜 界島南西部において, 砂丘の分布, 形態, 堆積物, 年代，編年，形成環境に関していくつかの議論が なされてきた。すなわち，砂丘は，水天宮山を中 心として更新世の低位の段丘と完新世段丘上に広 く分布していること，さらに段丘との関係や土壤， 堆積物の固結度合いなどをもとにして北西岸より の完新世砂丘と内陸側の更新世砂丘に区分され, それらが接しているか，または更新世砂丘が完新 世砂丘に一部覆われていることなどが明らかにさ れた（三位・木越, 1966; 武永, 1968; 中川, 1969; 斎藤ほか, 1972 ほか)。

完新世砂丘については, 腐植層や考古遺物, ${ }^{14} \mathrm{C}$ 年代をもとに，砂丘の形成年代や固定期・移 動期が論じられ，ここでは $2,000 〜 4,000$ 年前 ごろの砂丘固定期の存在が指摘された（三位・木 越, 1966; 斎藤ほか, 1972; 角田, 1977; 成瀬・井上, 1987)。

更新世砂丘は, Dune-rock（能勢, 1971; 斎藤ほ か, 1972)，こう結砂丘 (Lithified dune; 成瀬 ・ 井上, 1987), 砂板 (武永, 1968; 斎藤ほか, 1972 ほか）と呼ばれる特徵的に固結した砂丘堆積物が 含まれ，その分布やタイプが論じられた（能勢， 1971）。更新世砂丘の形成期について，三位・木 


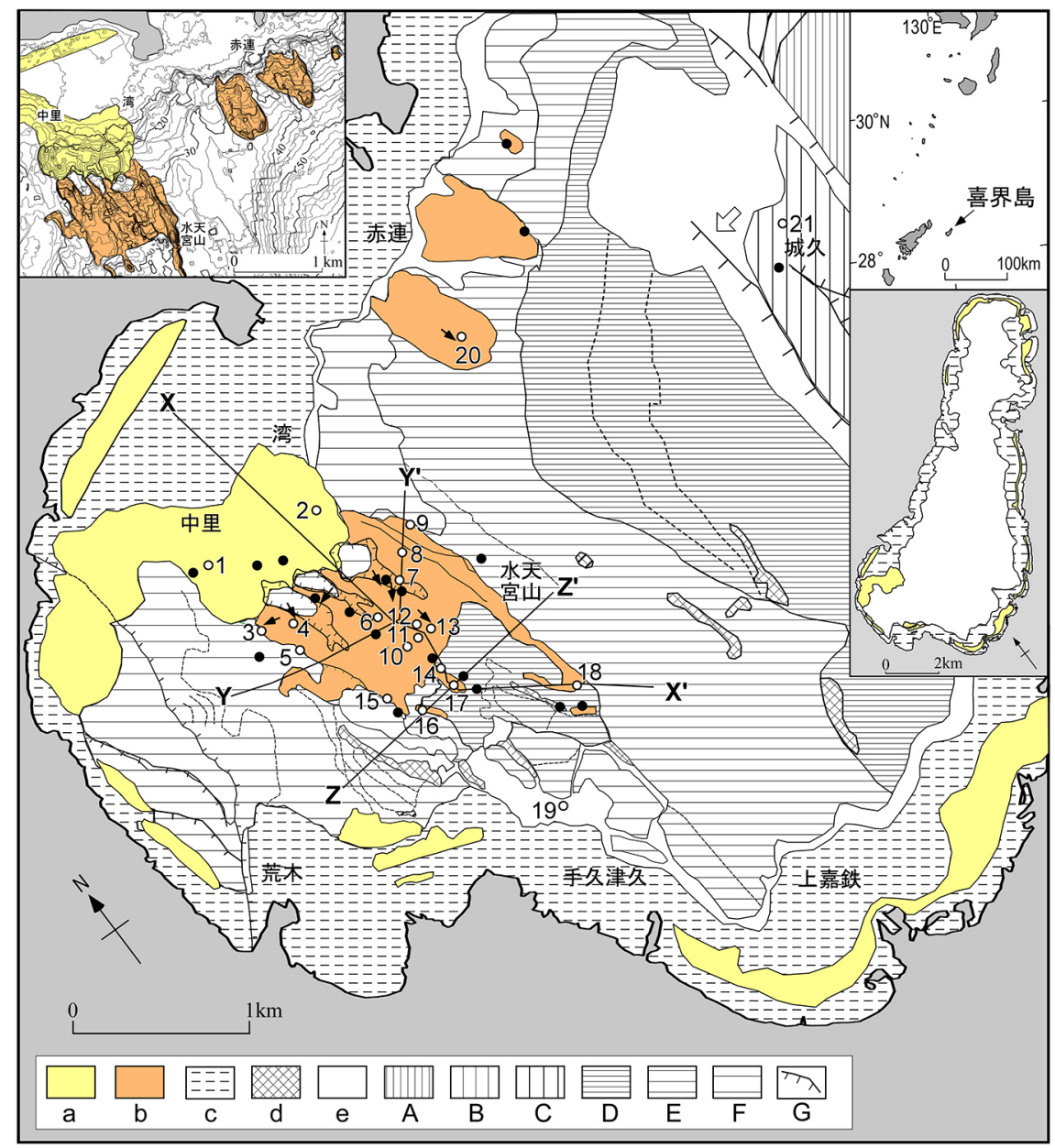

図 1 喜界島南西部の地形分類. $\mathrm{a}$ : 完新世砂丘, $\mathrm{b}$ : 更新世砂丘, $\mathrm{c}$ ：完新世海成段丘・低地・現海岸, $\mathrm{d}:$ 石灰岩丘, $\mathrm{e}$ ：崖・斜面， $\mathrm{A} \sim \mathrm{F}$ ：更新世海成段丘， A ：A 面 (MIS 5e), B : B 面 (MIS 5c), C : C 面 (MIS 5a), D : D 面 (MIS 3)，E：E面（MIS 3)，F：F 面（MIS 3)，G：断層・段丘の地形分類は Moriwaki（2016）による. 段丘面

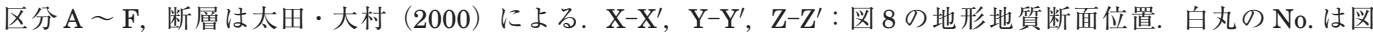
3 の柱状図の地点 No. と同じ. 黒丸印は観察した他の露頭位置. 黒矢印は更新世砂丘堆積物の層理の走向から知 られる風向。左上図は砂丘地の等高線図 (間隔 $2 \mathrm{~m}$ ), 等高線は「国土地理院，基盤地図情報，数值標高モデル」 による，右端中図は喜界島の完新世砂丘（黄色）の分布，Moriwaki（2016）を修正.

Fig. 1 Landform classification at the southern part of Kikaijima. a: Holocene sand dune, b: Pleistocene sand dune, c: Holocene marine terrace, lowland, present coast, d: Limestone ridge, e: Cliff, slope, A-F: Pleistocene marine terrace, A: A terrace surface (MIS 5e), B: B terrace surface (MIS 5c), C: C terrace surface (MIS 5a), D: D terrace surface (MIS 3), E: E terrace surface (MIS 3), F: F terrace surface (MIS 3), after Moriwaki (2016) for terrace classification, after Ota and Omura (2000) for definition of terrace surface A-F. X-X', Y-Y', Z-Z': Positions of geomorphic and geologic profiles in Fig. 8. No. at white circle: Same as column No. of Fig. 3. Black circles: Localities of other outcrops observed. Black arrow: Wind direction found from strike of Pleistocene sand beds. Upper left inset: Contour map spaced at $2 \mathrm{~m}$ intervals, after Geospatial Information Authority of Japan for the contour. Middle right insect: Distribution of Holocene sand dunes on Kikaijima Island (yellow), modified from Moriwaki (2016). 


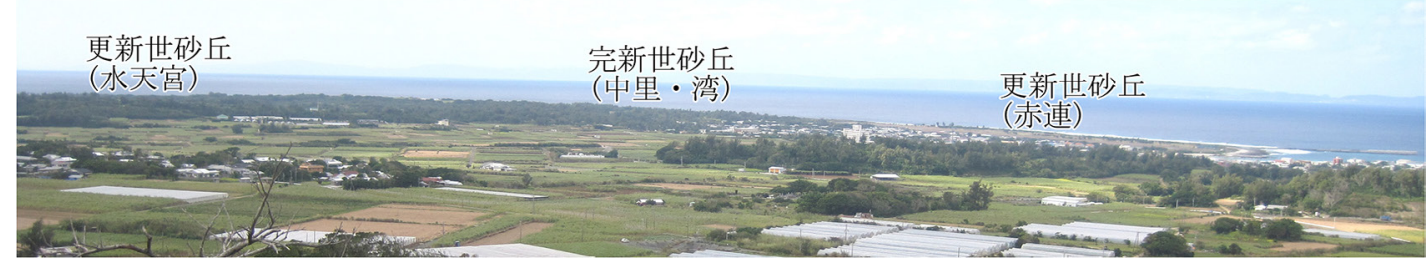

図 2 喜界島南西部の砂丘遠景. 城久地区から南東方向を臨む（図 1 の白抜き矢印).

Fig. 2 Distant view of sand dunes at the southwestern part of Kikaijima Island seen from Gusuku district to the southeast, which is shown by the white arrow in Fig. 1.

越（1966）は段丘との関係や固結度合いからビュ ルム末 (最終氷期末)，武永（1968）は更新世の 最低位段丘形成末期と考えた。その後, 成瀬・井 上（1987）は，砂丘堆積物での ${ }^{14} \mathrm{C}$ 年代測定資 料から水天宮地区の更新世砂丘は最終水期の形成 であることを示し，石灰質風成砂層が氷期に形成 されている特異なところであることを指摘した。 更新世砂丘の形成環境について，三位（1965） は乾燥気候で強い北西季節風の環境下で，角田 （1975）は汀線から多量の砂が形成される気候条 件下で形成されたと推測した。

南西部での更新世砂丘の分布地は，南西側の中 里から荒木にかけての地区と，これより北東側の 赤連の地区の 2 か所にある。それらはいくつか の呼称があるが，ここでは，便宜上，南西側の水 天宮山周辺の更新世砂丘地帯を水天宮砂丘地带, 中里地区を中心としたより海岸側の完新世砂丘地 帯を中里砂丘地帯，赤連地区の更新世砂丘を赤連 砂丘地帯と呼ぶことにする。

顕著な陸上河川のないサンゴ礁段丘からなる喜 界島は，砂丘砂供給源が限定されること，最終間 水期だけでなく最終水期中の亜間水期に形成され た時代を異にする海岸が段丘とて分離して陸上に みられることから，最終間水期以降の海岸と砂丘 形成の関係を検討するのに好条件をもつ。さらに 年代・編年資料も多く得られることから，砂丘形 成と, 海面変化, これに伴う海岸環境の変化, 気 候変化などとの関係を検討するのに好都合な地域 となっている。

喜界島の砂丘に関わる研究はおもに 2000 年以 前になされ, 長く研究が途絶えていたが, その間,
年代測定法やテフラ, 古環境に関する研究が進展 し，これらの知見をもとに，喜界島の砂丘の編年 や形成環境もさらに精度よく深化させることが可 能となった。これを進める上で，テフラは，地形 や堆積物の年代決定や対比・編年に大変有効であ る（町田・新井, 2003)。喜界島において, テフ ラの存在が報告された例はあるが（成瀬・井上, 1987），系統的に識別・編年されたものはなく， したがって，テフラが砂丘や段丘地形の編年に適 用された報告はない。砂丘の形成や，これと深く 関わる海成段丘の形成について確度の高い形成期 を特定することや，数多くなされてきた更新世・ 完新世の海成段丘の形成年代とのクロスチェック を行う意味でも，テフラの知見は重要である。今 回喜界島に抢いていくつかのテフラを見いだし， その識別・同定・編年を行い, 砂丘の編年に適用 した。

近年，喜界島の耕作地の整理事業にともなっ て, 砂丘や段丘の堆積物が広く露出し, 分布や編 年，形成環境を検討する新しい資料を得ることが 可能となった。喜界島の砂丘については，その地 形の概略を報告した（Moriwaki, 2016）。本稿で は，喜界島南西部の砂丘地带でのこうした新露頭 での知見から，完新世と更新世の砂丘の分布と構 造を明らかにし，さらに，テフラ， ${ }^{14} \mathrm{C}$ 年代，サ ンゴ礁段丘との関係などから砂丘の地形と堆積物 の編年を行い, その形成環境を検討する。

\section{II. 方 法}

砂丘の分布は，地形図と空中写真によって判読 し，現地での堆積物観察で確認した。とくにここ 

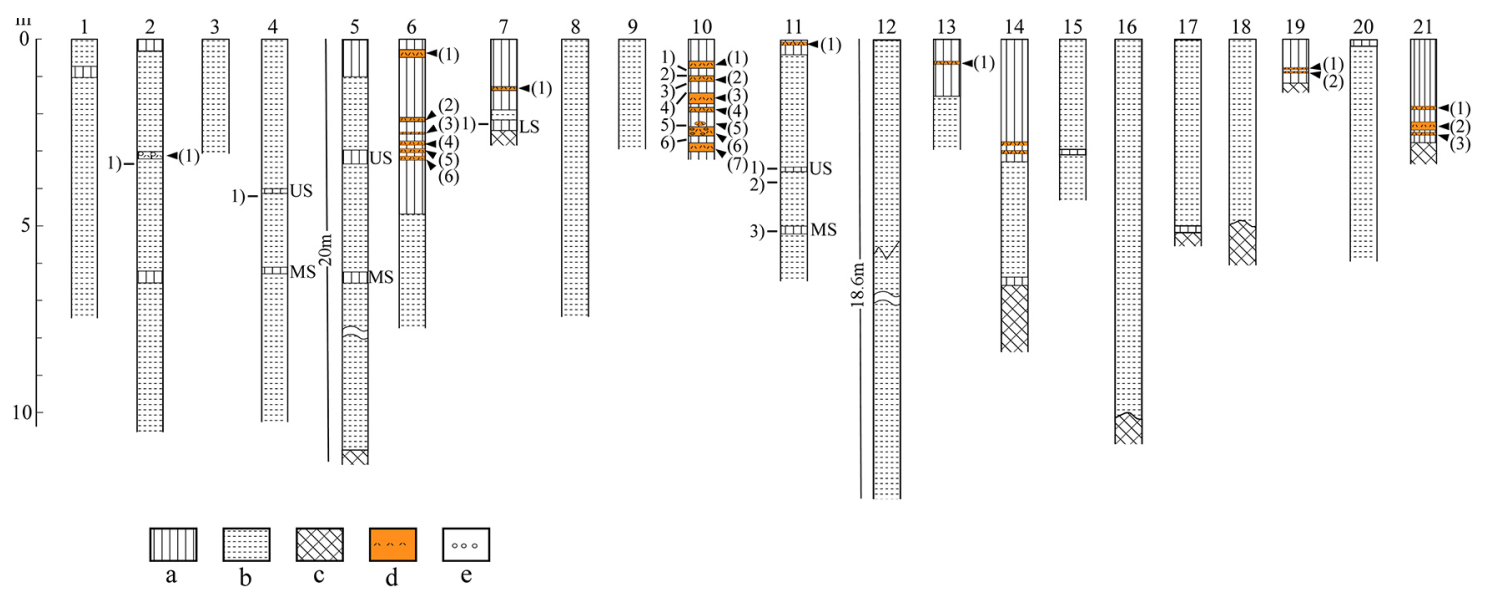

図 3 露頭柱状図. $\mathrm{a}$ : 土壤, $\mathrm{b}$ : 砂, $\mathrm{c}$ : 段丘堆積物, $\mathrm{d}$ : 火山灰, e : 軽石, US : 上位埋没土壤, MS : 中位埋没土壤, $\mathrm{LS}$ : 下位埋没土畩, (1) (6) : テフラ試料採取位置. 1) 6) : ${ }^{14} \mathrm{C}$ 年代測定位置, No. 10 のテフラに関わる年代 は表 3 参照, 砂丘に関わる年代は表 4 参照. 柱状図の地点 No. と試料 No. は図 1 , 表 $1,3,4$ と同じ.

Fig. 3 Sections of deposits. a: Soil, b: Sand, c: Terrace deposit, d: Volcanic ash, e: Pumice, (1)-(6): Horizon of tephra sample, 1)-6): Horizon of sample for ${ }^{14} \mathrm{C}$ measurement. See Table 3 and Table 4 for ages of tephras of the No. 10 section and those of sand dunes, respectively. Column No. and sample No.: Same as those in Fig. 1, Table 1, Table 3, and Table 4.

では，サンゴ段丘特有の基盤の小丘である石灰岩 丘との識別が注意を要する点で，耕地整理によっ て面的に広く露出した堆積物の現地調査で，砂丘 とサンゴ礁段丘との識別をすることができた。砂 丘堆積物の構造は, 従来の露頭に加え, 広く露出 した堆積物の観察をもとに求めた。

テフラに関して, 喜界島は給原火山より離れて いることと, サンゴ礁段丘は平坦ではあるが土壌 の発達が一様ではないことから，テフラが累積し やすい厚い土壤層が認められるところは限られ る。今回, 厚い土壤層中に累積するテフラ断面を 見いだした（図 $3:$ No.6，10，19，21）。これら の断面でのテフラ層序を基本に, その他の地点に おいて断片的に見いだされるテフラを加えて，層 相的特徵, 特徵鉱物, 屈折率（火山ガラス・斑晶 鉱物), 一部は火山ガラスの化学組成などを分析 総合してテフラの識別を行った。さらに既知の広 域テフラとテフラ間の土壤の ${ }^{14} \mathrm{C}$ 年代から, テフ ラの基本的な層序・編年を確立した（図 3,4 ,

5 , 表 $1,2,3)$ 。屈折率と化学組成は東京都立 大学の屈折率測定装置 RIMS, エネルギー分散型 $\mathrm{X}$ 線マイクロアナライザーによって求めた。
${ }^{14} \mathrm{C}$ 年代については，これまでの報告で較正さ れていない ${ }^{14} \mathrm{C}$ 年代も示されている。これについ ては，年代值の後に ${ }^{14} \mathrm{C}$ を付す。

砂丘堆積物に含まれる陸産貝類化石と基底のサ ンゴ礁に含まれるサンゴ片の ${ }^{14} \mathrm{C}$ 年代を測定し, テフラ編年とあわせて砂丘の形成年代を検討した。

\section{III. テ フ ラ}

上記の方法により, 全部で 9 層のテフラが識 別される（図 5 )。ここで鍵となるテフラは, 広 域に認定され, 喜界島周辺域でも広く認められて いる姶良 $\mathrm{Tn}$ テフラ（AT） と鬼界アカホヤテフ ラ（K-Ah）である（町田・新井, 2003）。

\section{1) $\mathbf{A T}$}

$\mathrm{AT}$ は上位から 8 層目のテフラである。このテ フラは，特徴的に明橙色のガラス質火山灰からな る。それはバブルウォール型の火山ガラスを主体 とし，その屈折率 $n$ は $1.496 \sim 1.500$ である（表 1)。こうした特徵は，すでに周辺域でも認めら れているATのそれ（森脇ほか, 2009）と一致し, このテフラは ATに同定される。AT は, 厚いと ころでは $30 \mathrm{~cm}$ 以上あり, 上部が下部よりも粗 


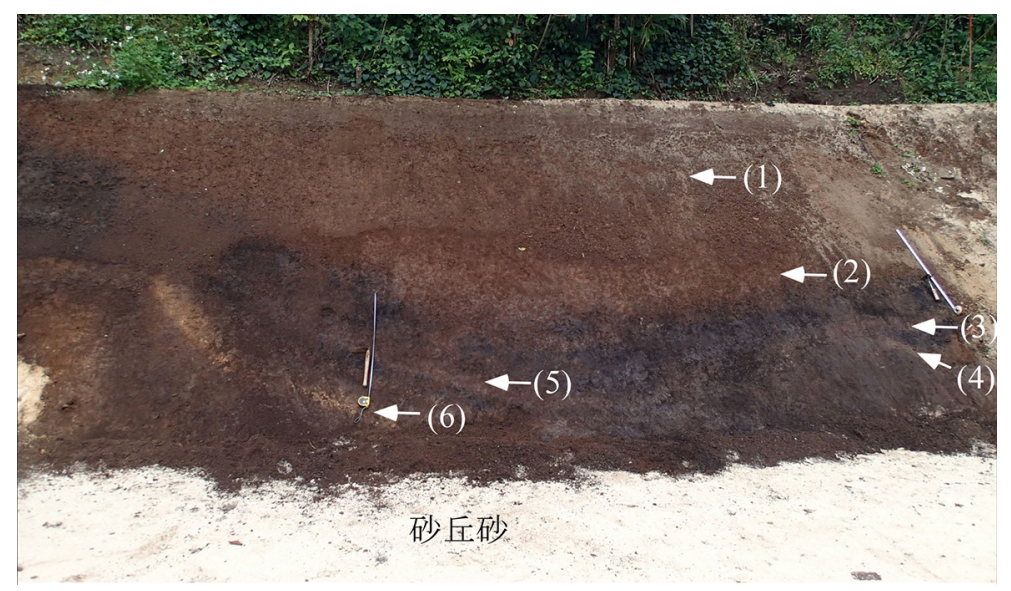

図 4 No. 6 地点のテフラ露頭断面. 矢印 : テフラ, 露頭位置は図 1 参照.

Fig. 4 Tephra sequence at locality of No. 6. Arrow shows tephra. See Fig. 1 for the locality.

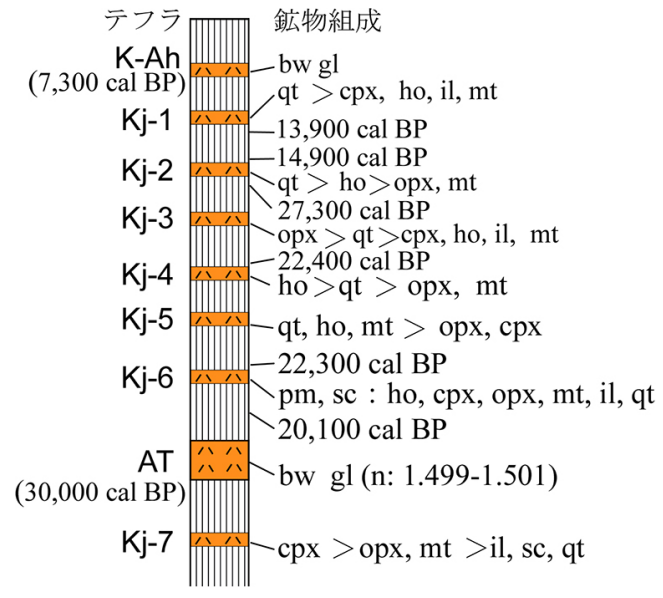

図 5 テフラの基本層序. 凡例は図 3 参照.

Fig. 5 Composite tephra stratigraphy. See Fig. 3 for the legend.

粒である（図 3 , 図 $4:$ No. 6-(6), No. 21-(2))。 その層位・年代については多くの報告があるが (町田・新井, 2003 ほか), ここでは，水月湖での 高精度な年代 30,000 cal BP (Smith et al., 2013) を採用しておく。この年代は, 海洋酸素同位体久 テージ 3 (MIS 3) の末に相当する。南九州周辺 の海底コアの酸素同位体記録からも，この時期の 層準にAT が認められている（Ijiri et al., 2005; 池原ほか, 2006)。

\section{2) K-Ah}

K-Ah は, No. 2 地点の腐植層のなかから独立 して見いだされた（図 3：No. 2-(1))。野外にお いて肉眼では観察できないが，土壤を洗浄するこ とによって特徴的な火山ガラスが抽出される。そ れは，バブルウォール型の火山ガラスで，淡褐色 のガラスを含む。火山ガラスの化学組成は，表 2 に示したように，姶良市別府川上流でみられる $\mathrm{K}-\mathrm{Ah}$ のそれと類似する。こうした特徴と層位か ら，この火山灰は K-Ah に同定される。屈折率 $n$ は $1.499 \sim 1.513$ と幅が広く，これは未水和の 部分が残存していることが関わっていると解釈さ れる。下に述べる $\mathrm{Kj}$ テフラ群との層位関係は,

$\mathrm{Kj}-1$ の土潩断面での層位と ${ }^{14} \mathrm{C}$ 年代資料からす ると，喜界島のテフラ層序のなかでは最上位にあ るとみられる。 $\mathrm{AT}$ と同様にその層位・年代も数 多く出されている。その年代は 7,300 年前であ る (Kitagawa et al., 1995; Smith et al., 2013)。 その層位は縄文海進最盛期にあたることから, $\mathrm{K}-\mathrm{Ah}$ は以下で示すようにこの時期の海岸環境を 編年するのに役立つ。

\section{3) 喜界島テフラ群 $(\mathbf{K j})$}

\section{3-1）識別}

$\mathrm{Kj}$ テフラ群は, 濃い橙色の火山灰または極細 粒軽石からなる。野外でのそれぞれの識別は，複 
表 1 テフラの鉱物組成.

Table 1 Mineral composition of tephras.

\begin{tabular}{|c|c|c|c|}
\hline $\begin{array}{c}\text { 地点 } \\
\text { No. }\end{array}$ & $\begin{array}{l}\text { 試料 } \\
\text { No. }\end{array}$ & $\begin{array}{c}\text { 主要鉱物"1) } \text { · ガラス } \\
\text { (gl:n) }\end{array}$ & $\begin{array}{l}\text { 同定 } \\
\text { テフラ }\end{array}$ \\
\hline No. 2 & (1) & gl (bw gl, br gl) & $\mathrm{K}-\mathrm{Ah}$ \\
\hline No. 6 & (1) & $\mathrm{qt}(\beta$-qt $)>\mathrm{cpx}$, ho $>\mathrm{mt}$, il & $\mathrm{Kj}-1$ \\
\hline No. 6 & $(2)$ & $\mathrm{qt}(\beta-\mathrm{qt})>$ ho $>\mathrm{opx}, \mathrm{mt}$ & $\mathrm{Kj}-2$ \\
\hline No. 6 & (3) & opx $>$ qt $(\beta-q \mathrm{t})$, ho, $\mathrm{mt}$ & $\mathrm{Kj}-3$ \\
\hline No. 6 & (4) & ho, $\mathrm{qt}(\beta$-qt $)>\mathrm{opx}, \mathrm{mt}$, qt & $\mathrm{Kj}-4$ \\
\hline No. 6 & (5) & ho, qt, mt > opx, cpx & $\mathrm{Kj}-5$ \\
\hline No. 6 & (6) & $\mathrm{gl}(\mathrm{bw} \mathrm{gl})>\mathrm{opx}, \mathrm{ho}, \mathrm{qt}$ & $\mathrm{AT}$ \\
\hline No. 7 & (1) & f. $\mathrm{pm}>\mathrm{sc}>\mathrm{cpx}, \mathrm{opx}, \mathrm{qt}(\beta$-qt $)$ & $\mathrm{Kj}-6$ \\
\hline No. 10 & (1) & $\mathrm{qt}(\beta$-qt $)>\mathrm{cpx}$, ho $>\mathrm{mt}$, il & $\mathrm{Kj}-1$ \\
\hline No. 10 & $(2)$ & $\mathrm{qt}(\beta-\mathrm{qt})>\mathrm{ho}>\mathrm{opx}, \mathrm{mt}$ & $\mathrm{Kj}-2$ \\
\hline No. 10 & (3) & $\mathrm{qt}(\beta$-qt $), \mathrm{ho}>\mathrm{opx}, \mathrm{mt}$ & $\mathrm{Kj}-4$ \\
\hline No.10 & (4) & $\mathrm{gl}(\mathrm{bw} \mathrm{gl})>\mathrm{mt}, \mathrm{qt}, \mathrm{cpx}$ & $\mathrm{AT}$ 二次 \\
\hline No.10 & (5) & $\mathrm{gl}(\mathrm{bw} \mathrm{gl})>\mathrm{mt}$, qt, ho & $\mathrm{AT}$ 二次 \\
\hline No.10 & (6) & f. $p m>q t, h o, m t, s c$ & $\mathrm{Kj}-6$ \\
\hline No.10 & (7) & $\mathrm{gl}(\mathrm{bw} \mathrm{gl})$ & $\mathrm{AT}$ \\
\hline No.11 & (1) & opx, mt $>$ ho, cpx, qt & $\mathrm{Kj}-3$ \\
\hline No.13 & (1) & $\mathrm{qt}(\beta-\mathrm{qt})$, ho $>$ opx & $\mathrm{Kj}-2$ \\
\hline No.19 & (1) & opx, cpx, lmt, qt $(\beta$-qt $)$ & $\mathrm{Kj}-3$ \\
\hline No.19 & $(2)$ & ho, $\mathrm{qt}(\beta$-qt $)>$ opx & $\mathrm{Kj}-4$ \\
\hline No.21 & (1) & ho, $\mathrm{qt}(\beta-\mathrm{qt})$ & $\mathrm{Kj}-4$ \\
\hline No.21 & $(2)$ & $\mathrm{gl}(\mathrm{bw} \mathrm{gl})(\mathrm{n}: 1.498-1.500)$ & $\mathrm{AT}$ \\
\hline No.21 & (3) & opx $>c p x, q t(\beta-q t)$, sc, il, mt & $\mathrm{Kj}-7$ \\
\hline
\end{tabular}

$\mathrm{gl}$ : 火山ガラス, opx: 斜方輝石, $\mathrm{cpx}$ : 単斜輝石, ho:角閃石, $\mathrm{mt}$ : 磁鉄鉱, il : チタン鉄鉱, qt : 石英, f.pm : 細粒軽石, $\mathrm{sc}$ ：スコリア.*1) 括弧内は特徵的に含む鉱物, $\mathrm{bw} \mathrm{gl}:$ バ ブルウォール型ガラス, br gl : 褐色ガラス, $\beta$-qt : 高温石 英, No. 21 の $n$ : は火山ガラスの屈折率.

gl: Volcanic glass, opx: Orthopyroxene, cpx: Clinopyroxene, ho: Hornblende, mt: Magnetite, il: Ilmenite, qt: Quartz, f.pm: Fine pumice, sc: Scoria. *1) Parentheses denote characteristic minerals or glasses, bw gl: Bubble-walled glass, br gl: Brown glass, $\beta$-qt: $\beta$-quartz. $n$ : denotes refractive index of volcanic glass.

数のテフラが累積し, 層序の明確なセクション 以外容易ではない。岩石記載的性質も類似し, 識別に関わるものとしては石英 $(\mathrm{qt})$, 角閃石 (ho), 斜方輝石 (opx), 単斜輝石 (cpx), 磁鉄 鉱 (mt)，チタン鉄鉱（il）が抢もなものである。 火山ガラスは基本的には残存していない。これら のテフラは，全体として，バブルウォール型の火 山ガラスからなる AT, K-Ah とは明瞭に識別さ れる。特徵鉱物に着目すると各テフラに違いが認
められるものもあり，これと野外で観察した層序・ 層位とをあわせると，各テフラの識別は可能であ る。その結果 7 層のテフラが認められる（表 1 , 図 3，4)。これらのテフラを上位から喜界島 1 テフラ $(\mathrm{Kj}-1)$ ～喜界島 7 テフラ $(\mathrm{Kj}-7)$ と名づ ける（図 5 )。

以下に識別指標となる特徵的な層位，層相，鉱 物について述べる（表 1 , 図 $3 ， 5$ ）。テフラの 厚さはおもにNo. 6,10 地点のものである。

$\mathrm{Kj}-1$ は，厚さ約 $20 \mathrm{~cm}$ で，qtがもっとも多い。 特徵的に $\beta$-qt を含む。他に淡緑色の $\mathrm{cpx}$, ho を 含む。 $\mathrm{Kj}-2$ は厚さ $13 \mathrm{~cm}$ で, $\beta$-qt と ho がとくに 多い。Kj-3 は厚さ $7 \sim 10 \mathrm{~cm}$ で, opxをとくに 多く含む。 $\mathrm{Kj}-4$ は厚さ $10 \mathrm{~cm}$ で, qt とくに $\beta$-qt と ho を多く含み, 他は少ない。この点は $\mathrm{Kj}-2$ と 類似する。 $\mathrm{Kj}-5$ は厚さ $10 \mathrm{~cm}$ で, $\beta$-qt, ho を多 く含む。 $\mathrm{Kj}-2, \mathrm{Kj}-4$ と類似するが, $\mathrm{Kj}-2, \mathrm{Kj}-4$ と同一露頭断面で層位を異にして認められるた め，異なるテフラである（図 4$)$ 。 Kj-6 は厚さ $25 \mathrm{~cm}$ で, 径 $1 \mathrm{~mm}$ 以下の細粒軽石粒からなる。 場所によって厚く堆積しているところでは固結し ている。スコリアを多く含む。Kj-7 は，MIS 5a 面上にある城久で見いだされた（図 1 , 図 3 : No. 21)。ATより下位にある。濃橙色の火山灰で, 厚さ $3 \mathrm{~cm}$ でパッチ状に堆積する。主要な構成鉱 物は cpx, opx でil, mt, qt $(\beta$-qt), スコリア を含む。

\section{3-2) 対比と給源}

$\mathrm{AT}$ より上位の $\mathrm{Kj}-1$ ～Kj-6 テフラ群は，近隣 西方のトカラ列島の諸火山に由来すると考えられ る。トカラ列島の諸火山のテフラは，森脇ほか （2009）により全体的な層序と編年がなされてい るが，岩石記載的性質などの詳しい指標に基づく 対比については今後の検討課題である。非火山性 外帯の島々では，徳之島の小島における筆者らの 観察では，AT の上位に顕著なテフラが 3 層認め られる。このうちの最下位のテフラは, 同じ露頭 において小林 (2013) がオレンジ火山灰と呼ん だもの，上位の 2 層のうちのどちらかは泥質火 山灰と呼んだものに相当する。最下位のテフラ（才 レンジ火山灰）はおもな鉱物が $\mathrm{cpx}, \mathrm{opx}, \mathrm{mt}$ か 
表 2 完新世砂丘堆積物中の火山ガラスの化学組成.

Table 2 Chemical composition of volcanic glass in Holocene sand dune deposits.

\begin{tabular}{llrrrrrrrrrrrr}
\hline & $\mathrm{SiO}_{2}$ & $\mathrm{TiO}_{2}$ & $\mathrm{Al}_{2} \mathrm{O}_{3}$ & $\mathrm{FeO}$ & $\mathrm{MnO}$ & $\mathrm{MgO}$ & $\mathrm{CaO}$ & $\mathrm{K}_{2} \mathrm{O}$ & $\mathrm{Na}_{2} \mathrm{O}$ & $\mathrm{Total}$ & $\mathrm{n}$ \\
\hline \multirow{2}{*}{ 喜界島 No.2-(1) } & 平均 & 74.50 & 0.56 & 13.26 & 2.39 & 0.14 & 0.56 & 2.00 & 2.71 & 3.88 & 100 & 96.47 & 13 \\
& 標準偏差 & 0.30 & 0.10 & 0.07 & 0.09 & 0.07 & 0.02 & 0.08 & 0.07 & 0.12 & 0 & 1.82 & \\
& 平均 & 74.46 & 0.60 & 13.10 & 2.52 & 0.18 & 0.55 & 2.01 & 2.78 & 3.81 & 100 & 98.26 & 20 \\
K-Ah* & 標準偏差 & 0.20 & 0.07 & 0.08 & 0.09 & 0.07 & 0.03 & 0.05 & 0.07 & 0.09 & 0 & 1.01 \\
\hline
\end{tabular}

地点・層位 (No. 2-(1)) は図 3, 6 参照. *K-Ah 試料採取地点 : 姶良市別府川上流， $n$ : 測定個数.

Location and stratigraphic position of No. 2-(1) are shown in Fig. 3 and Fig. 6. *K-Ah sampling site: Upper reaches of Beppu river, $n$ : Number of analysis.

表 3 テフラにかかわる ${ }^{14} \mathrm{C}$ 年代 (No. 10 地点).

Table $3{ }^{14} \mathrm{C}$ ages for tephras (Loc. No. 10).

\begin{tabular}{ccccccc}
\hline 地点 No. & 試料 No. & 試料層位 & ${ }^{14} \mathrm{C}$ 年代 $(\mathrm{yr} \mathrm{BP})$ & 較正暦年代 cal BP $(2 \delta)($ 中央值 $)$ & 測定番号 \\
\hline No.10 & $1)$ & $(1)(\mathrm{Kj}-1)$ 直下 & $12080 \pm 35$ & $14071 \sim 13781(13,926)$ & PLD-40633 \\
No.10 & $2)$ & $(2)(\mathrm{Kj}-2)$ 直上 & $12530 \pm 35$ & $15065 \sim 14801(14,933)$ & PLD-41781 \\
No.10 & $3)$ & $(2)(\mathrm{Kj}-2)$ 直下 & $22950 \pm 70$ & $27481 \sim 27093(27,287)$ & PLD-40634 \\
No.10 & $4)$ & $(3)(\mathrm{Kj}-4)$ 直上 & $18410 \pm 45$ & $22458 \sim 22248(22,353)$ & PLD-41782 \\
No.10 & $5)$ & $(6)(\mathrm{Kj}-6)$ 直上 & $18450 \pm 60$ & $22496 \sim 22151(22,324)$ & PLD-40635 \\
No.10 & $6)$ & $(6)(\mathrm{Kj}-6)$ 下位 & $16590 \pm 45$ & $20206 \sim 19896(20,051)$ & PLD-41783 \\
\hline
\end{tabular}

測定試料の地点と層位は図 1,3 の No. 10 参照. 位置 : 北緯 $28^{\circ} 18^{\prime} 14^{\prime \prime}$, 東経 $129^{\circ} 56^{\prime} 02^{\prime \prime}$. 測定試料はいずれも腐植土.

See Fig. 1 and Fig. 3 for locality and sample numbers. Location: $28^{\circ} 18^{\prime} 14^{\prime \prime} \mathrm{N}, 129^{\circ} 56^{\prime} 02^{\prime \prime} \mathrm{E}$. All samples dated are humic soil.

らなり，qt，hoを含まない。喜界島の $\mathrm{Kj}$ テフラ 群は qt，hoを含むので，オレンジ火山灰に該当 するものはない。筆者らの観察によると，徳之島 のオレンジ火山灰は比較的粗粒な軽石からなり, 奄美諸島一帯に分布することが予想される。給源 は徳之島西方の硫黄鳥島とみられるが，硫黄鳥島 の陸上にはこのような降下軽石層はみられない。 一方，徳之島の上位 2 層のテフラは細粒の灰色 火山灰で，特徴的に $\beta$-qt と ho を含む。この特徵 は，喜界島の $\mathrm{Kj}-2, \mathrm{Kj}-4, \mathrm{Kj}-5$ のそれに類似し， 徳之島の上位の 2 層の火山灰に対比される可能 性をもつ。

$\mathrm{Kj}-7$ について，喜界島周辺の島々で見いださ れたテフラで対比候補として考えられるのは，層 位と規模からみてトカラ列島の口之島の Kc-5, 悪石島の Ak-Y5（森脇ほか, 2009), 種子島の種
III，種 IV (Nagaoka, 1988; 奥野・小林, 1994; Okuno et al., 2012）である。このうち, 種 III, 種 IV はスコリア (sc), qt を含み, Kc-5, Ak-Y5 はこれらを含まない。 sc，qtを含む $\mathrm{Kj}-7$ は，鉱 物組成からは種 III，種 IV に類似するが，斜方 輝石の屈折率 $(\gamma)$ の值が異なり, 対比されない。 すなわち, 斜方輝石 $(\gamma)$ の屈折率は, $\mathrm{Kj}-7$ は $1.718 \sim 1.723$ (中央值 1.720）であるのに対し, 種 III が $1.706 〜 1.711$ (1.709)，種 IV が 1.701 〜 1.704 (1.703), $1.708 \sim 1.711$ (1.710) であ る。

このように, $\mathrm{Kj}$ テフラ群は硫黄鳥島に由来す るとみられるテフラのある徳之島などで，一部対 比されるものがあるが，他の南西諸島の島々では 知見がなく, その分布, 給源の解明は今後の課題 となる。 


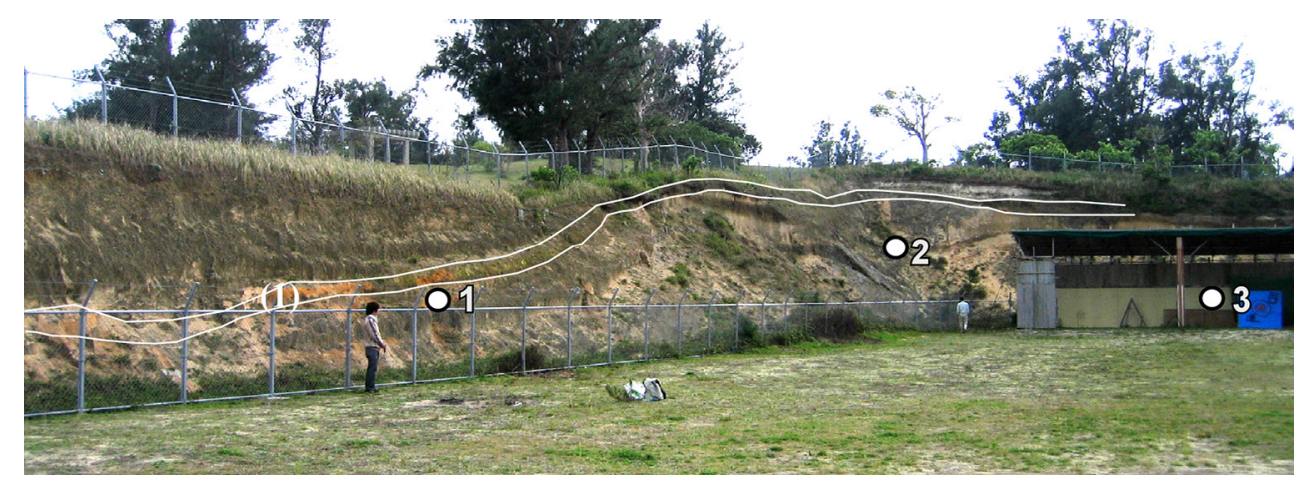

図 6 完新世砂丘堆積物と年代 (図 1 の No. 2 地点). (1): K-Ah 火山ガラスを含む腐植層, 火山ガラスの化学組成は表 2 の No. 2-(1)参照. 1：7,450 cal BP. 2：7,800 cal BP（横尾, 2012)：正確には特定できないが, K-Ahを含む腐植 層と土器包含層 No. 3 の間の No. 2 の層準付近にあると判断される. $3: 7,800 \mathrm{cal} \mathrm{BP}$ (澄田ほか, 2003).

Fig. 6 Holocene sand dune section and ages at locality No. 2 (Fig. 1). (1): Humic layer containing K-Ah glass shards, of which chemical composition is shown in Table 2 (No. 2-(1)). 1: 7,450 cal BP. 2: 7,800 cal BP (Yokoo, 2012). The position cannot be determined precisely, but it probably lies at around position No. 2 between the humic soil containing K-Ah and No. 3 soil containing earthenware. 3: 7,800 cal BP (Sumita et al., 2003).

\section{3-3) 年代}

いくつかのテフラが累積するNo. 10 地点で の ${ }^{14} \mathrm{C}$ 年代は, $\mathrm{Kj}$ テフラ群は $13,000 \mathrm{cal} \mathrm{BP}$ と 30,000 cal BP の間に入ることを示す（表 3 , 図 $3)$ 。個々のテフラについては, 上位の (1) $(\mathrm{Kj}-1)$ は約 14,000 cal BP，（2）（Kj-2）は約 15,000 年 前とみて矛盾はない。下位の No. 10-3)の年代か ら下位は，年代が逆転しているところがあり，

（Kj-4）と（6）（Kj-6）のテフラの年代を特定す ることはできないが，これらのテフラは 2 万年 前ごろから 3 万年前の間に入るものと推定され る。以上のことは，Kj テフラ群は，薩南諸島に おいて最終水期最盛期前後から晚水期にかけての 古環境と文化の編年を行う上で役立つことを示し ている。

\section{IV. 完新世砂丘}

\section{1) 砂丘の分布と地形}

完新世の砂丘は，喜界島の西岸以外のほぼ一円 の海岸沿いに分布する (図 1 右挿入図)。もっと も発達がいいのは喜界島南西部の中里・湾地区の 中里砂丘地帯である。他の砂丘地帯は細長く, 規 模が小さい。それらは現海岸沿いか完新世段丘の 海岸側にあり，縄文海進最盛期ごろの砂丘形成が
なかったことを示している。更新世段丘崖や段丘 上に乗り上げているのは北東岸と南西岸にある が，その規模は大きくない。

南西部の中里砂丘地帯は完新世段丘の内陸側だ けでなく背後の更新世段丘を厚く覆い, 縄文海進 最盛期ごろの砂丘形成の存在を示唆している（図 1 )。この砂丘の平面形態は比較的円形で，海岸 側が緩傾斜，陸側が急傾斜をなす。以下では良好 な編年資料が得られた喜界町弓道場（図 1:No. 2 地点）の砂丘堆積物を中心に検討する。

\section{2）砂丘堆積物と編年}

砂丘堆積物は, 全体として淘汰のよい中粒砂か らなり，層理は一般に不明瞭で，更新世砂丘のよ うに固結しているところはみられない。湾地区の 喜界町弓道場にあるNo. 2 地点（図 1 ）は内陸に あり，砂丘が背後の更新世砂丘と接する。この地 点はおよそ最大 $8 \mathrm{~m}$ の厚い砂丘堆積物中に複数 の腐植層-クロスナーや陸成巻貝，考古遺物が異な る層位にみられる（図 3,6 ）。腐植層は少なく とも 3 層ある。前記のように，このうち東側の 上部に挟まれる褐色の腐植層（厚さ $20 \mathrm{~cm}$ ） から K-Ah が検出された（図 $3:$ No. 2-(1), 眓 6 )。 したがって，これを含む腐植層は，7,300 年前ご ろに形成されたと考えられる。K-Ah を含む腐植 
層直下の砂丘堆積物から得られた陸成巻貝の年代 は 7,436 cal BP を示す（図 6 ，表 4 ）。喜界島に おいて報告された陸成巻貝の ${ }^{14} \mathrm{C}$ 年代には，より 古くなるような ${ }^{14} \mathrm{C}$ 年代異常を示すものがある（高 橋・和田, 1998; 高橋ほか, 1998)。それは，陸産 貝類は付着する古い石灰岩を取り込んで貝殼をつ くるため, 古い炭素が含まれる可能性があるこ とによるとされる（高橋・和田, 1998; 高橋ほか, 1998)。しかし，今回得られた年代はK-Ahの層 位と整合する。

$\mathrm{K}-\mathrm{Ah}$ を含む腐植層より下位の腐植層から土器 が出土し（図 6 中の 3), この土器に付着した炭 化物から，7,800 cal BP が得られている（表 4, 図 3，6；澄田ほか, 2003)。また，この 2 つの腐 植層の間にある貝化石からはいくつかの ${ }^{14} \mathrm{C}$ 年代 が得られている（表 4 , 横尾, 2012)，このなか の異常に古い年代を示すものは ${ }^{14} \mathrm{C}$ 年代異常によ ると考えられる陸成巻貝（高橋・和田, 1998; 高 橋ほか，1998）からの年代で，これを除いた海成 貝殼（サザエ）の年代は， 7,795 cal BPを示す (横尾, 2012)。今回得た $\mathrm{K}-\mathrm{Ah} と{ }^{14} \mathrm{C}$ 年代は, こ れらの既報告の ${ }^{14} \mathrm{C}$ 年代と整合する。

$\mathrm{K}-\mathrm{Ah}$ の火山ガラスが含まれる腐植層には軽 石が散在する（図 3,6 ）。平均の粒径は $2.5 \mathrm{~cm}$ で, 円磨されている。その火山ガラスの屈折率 $n$ は 1.496-1.499 で, ATすなわち入戸火砕流堆積 物のそれと一致する。したがって，この軽石は， 入戸火砕流堆積物に由来する軽石が海岸に漂着 し, 砂丘中に取り込まれたものと判断される。

弓道場の No. 2 地点より海岸側ではいくつかの 地点において砂丘砂に覆われる腐植層が認めら れ，陸成巻貝の年代から $3000 \sim 4500{ }^{14} \mathrm{C}$ 年前 が得られている（表 4, 三位・木越, 1966; 角田, 1977; 成瀬 ・井上, 1987; 高橋・和田, 1998)。角 田（1977）はこのころの喜界島南西部での完新 世砂丘の固定期の存在を指摘し，また，弓道場 No. 2 地点から $200 \mathrm{~m}$ ほど海岸側の総合グラン ド崖面での中里貝塚の知見（斎藤ほか, 1972）か ら，縄文後期〜晚期には砂丘の移動がこの地点で はなかったと指摘している。ここでの腐植層は, 内陸側の弓道場 No. 2 地点では，腐植層の年代 ·
層序からすると表層に近い最上位の腐植層にあた る。このことは $4,500{ }^{14} \mathrm{C}$ 年前以降, 砂丘砂はこ の地点にはほとんど達しなかったことを示す。

以上のことは，南西部での完新世砂丘はおよそ 8,000 年前から形成され，7,300 年前， 3,000 $4,500{ }^{14} \mathrm{C}$ 年前頃を含む何回かの固定期を挟んで 形成されてきたことを示す。

\section{V. 更新世砂丘}

\section{1）砂丘の分布と地形}

\section{1-1）水天宮砂丘地帯南部地区}

Moriwaki（2016）を修正した地形分類図（図 1）と, 観察した堆積物（図 3，7），地形と堆 積物から描いた地形・地質断面図（図 8) をも とに, 更新世砂丘の分布, 堆積物, 堆積の構造を 以下に述べる。

これまで水天宮砂丘は，喜界島南西部の中里か ら荒木に至る孤立した丘陵一帯に広く分布して いるとされてきた（図 1 ; Hanzawa, 1935; 武永, 1968; 中川, 1969 ほか)。しかし, 耕地整理や遊 水池掘削に伴って広く露出した場所での観察によ ると，更新世砂丘とされる丘陵の南部のほとんど は基盤のサンゴ石灰岩からなり，砂丘はこれらの 段丘を部分的に覆っているにすぎない。こうした 南部の独立した基盤のサンゴ段丘地帯は，D面， $\mathrm{E}$ 面からなっている（図 1)。

水天宮砂丘地帯の南部において, 段丘崖や崖上 にリッジ状に細長く分布する幾筋かの地形は，砂 丘のようにみえる。しかし今回の観察によると， それらの多くは基盤の石灰岩丘か，またはこうし た石灰岩丘上に乗り上げている砂丘で，全体が砂 丘砂によって構成されているわけではないことが 明らかとなった。それらの砂丘砂は下位の崖面に 続く。例えば，砂丘地帯の北縁で，水天宮山を含 み，南北方向に細長く延びるリッジは，少なくと も南側ではサンゴ石灰岩らなり，これに砂丘が東 側に沿う E 面から乗り上げた地形である（図 1 , 図 $3:$ No. 18)。したがって, 崖全体の比高が砂 丘砂の厚さを示さない。この砂丘は，E 面形成当 時の海の背後にある D 段丘に乗り上げた横列砂 丘となっている。このように水天宮砂丘地帯南部 


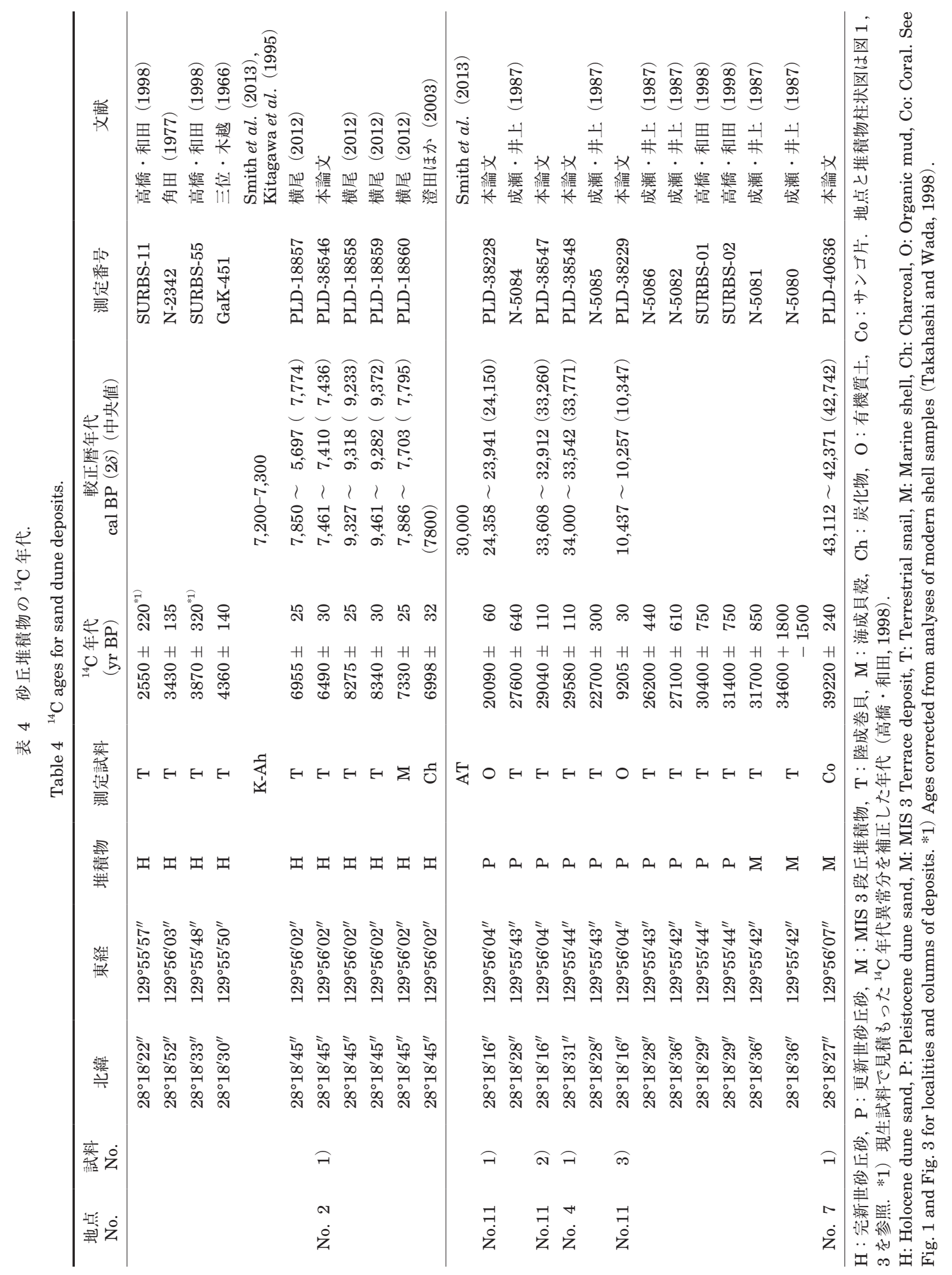




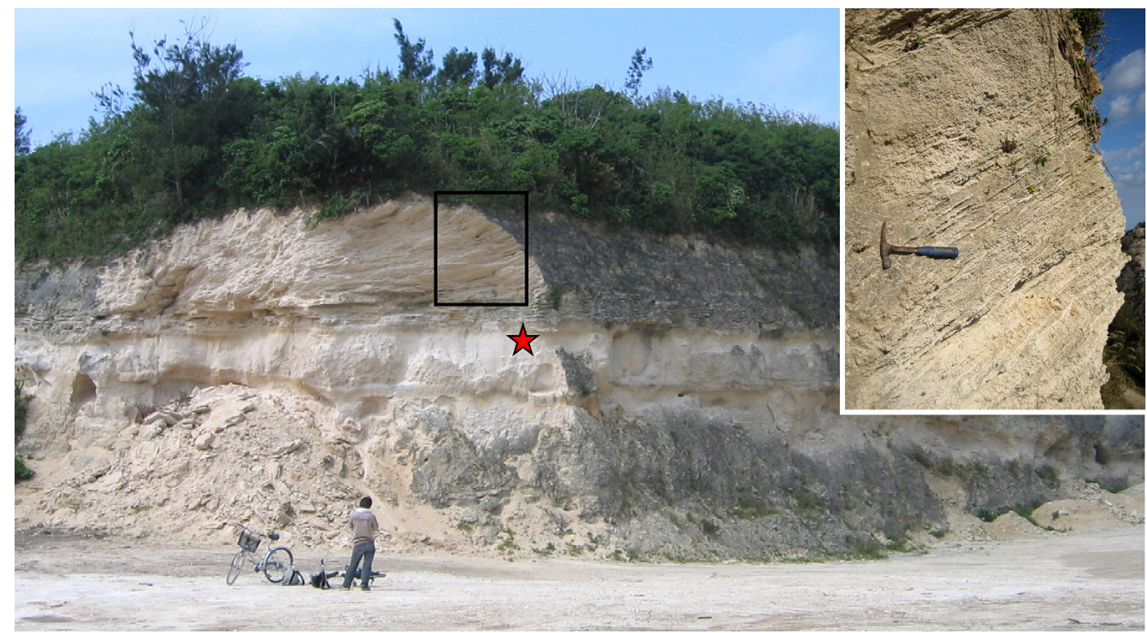

図 7 更新世砂丘堆積物 (水天宮砂丘地帯, No. 4 地点). 星印：33,771 cal BP，黒四角：右の扦入写真のおよその範囲. 撮影時期は異なる。露頭位置は図 1 , 柱状図は図 3 参照.

Fig. 7 Pleistocene sand dune section at locality No. 4 in Suitengu sand dune district. Star: 33,771 cal BP, See Fig. 1 for locality and Fig. 3 for the geologic column.

の更新世砂丘は，これらの段丘面上や段丘崖端， 段丘崖を覆っており，近接する下位の段丘面形成 当時の海浜の砂の供給によって，背後の段丘崖や 段丘面縁辺に順次形成されたことを示す。

\section{1-2）水天宮砂丘地帯北部地区}

水天宮砂丘地帯北部では，更新世砂丘は，南部 と異なり, 段丘面全体を厚く覆う。南部地帯と接 する南縁は，段丘崖を埋積したり，E，Dの段丘 面上に乗り上げている。北縁は完新世の砂丘と接 し，完新世砂丘に覆われる。他の周縁は最低位の $\mathrm{E} ， \mathrm{~F}$ 段丘面上にある。

この北部地区の砂丘地帯はその比高や形態から みると 2 種類ある。1つは東縁と西縁にあって， 背後の高い砂丘とは 1 段低く, 低平な砂丘であ る。それらは堆積物も薄く, 近接する海岸からの 横列砂丘として形成されたことを示す（図 1 ）。

他の 1 つは, 中央部の主要部分を占め, 前者 よりも比高が大きく，大規模な砂丘地帯である。 この砂丘は，比較的深い谷を挟む砂丘列が北西一 南東方向に長く配列する。南縁ではこの砂丘列は ロブ状に段丘面上で終わるところもある。後述す るように，砂丘列間の凹地を埋積する厚い土懔層 の編年に基づくと，凹地は，砂丘とほぼ同時期に
形成されたとみられることから，砂丘形成後の侵 食によってではなく砂丘形成時に砂丘間凹地とし て形成されたものである。角田（1977）が形態 から解釈した縦列砂丘がこの凹地編年から確認さ れる。

\section{1-3）赤連砂丘地帯}

水天宮砂丘地帯から北方に少し離れた赤連地区 にも更新世段丘面上に砂丘があり，その存在に ついては古くから多くの報告がされている（Hanzawa, 1935; 三位・木越, 1966; 武永, 1968; 中川, 1969; 能勢, 1971; 斎藤ほか, 1972)。ここにも, 水天宮砂丘地帯ほどではないが，これに近い規模 の砂丘が $\mathrm{F}$ 段丘面上にのる（図 1 )。ここには 3 つの砂丘区域があり，小規模な最北の砂丘は， $\mathrm{F}$ 面上に孤立し，明らかに $\mathrm{F}$ 面と同時期に形成され たことを示す。これより規模は大きい南側の他の 2 つも，F面上にある。それらは楕円状をなし， その長軸は水天宮砂丘地帯と同様に北西 - 南東 方向に延びる。その海岸側縁辺は完新世段丘背後 の段丘崖 $\mathrm{F}$ 面の段丘崖によって切られており， $\mathrm{F}$ 面と同時期の砂丘であることを示す。その尾根の 方向も，全体の地形の長軸の方向と同じで，また 水天宮砂丘の地形分布の長軸方向と一致する。 

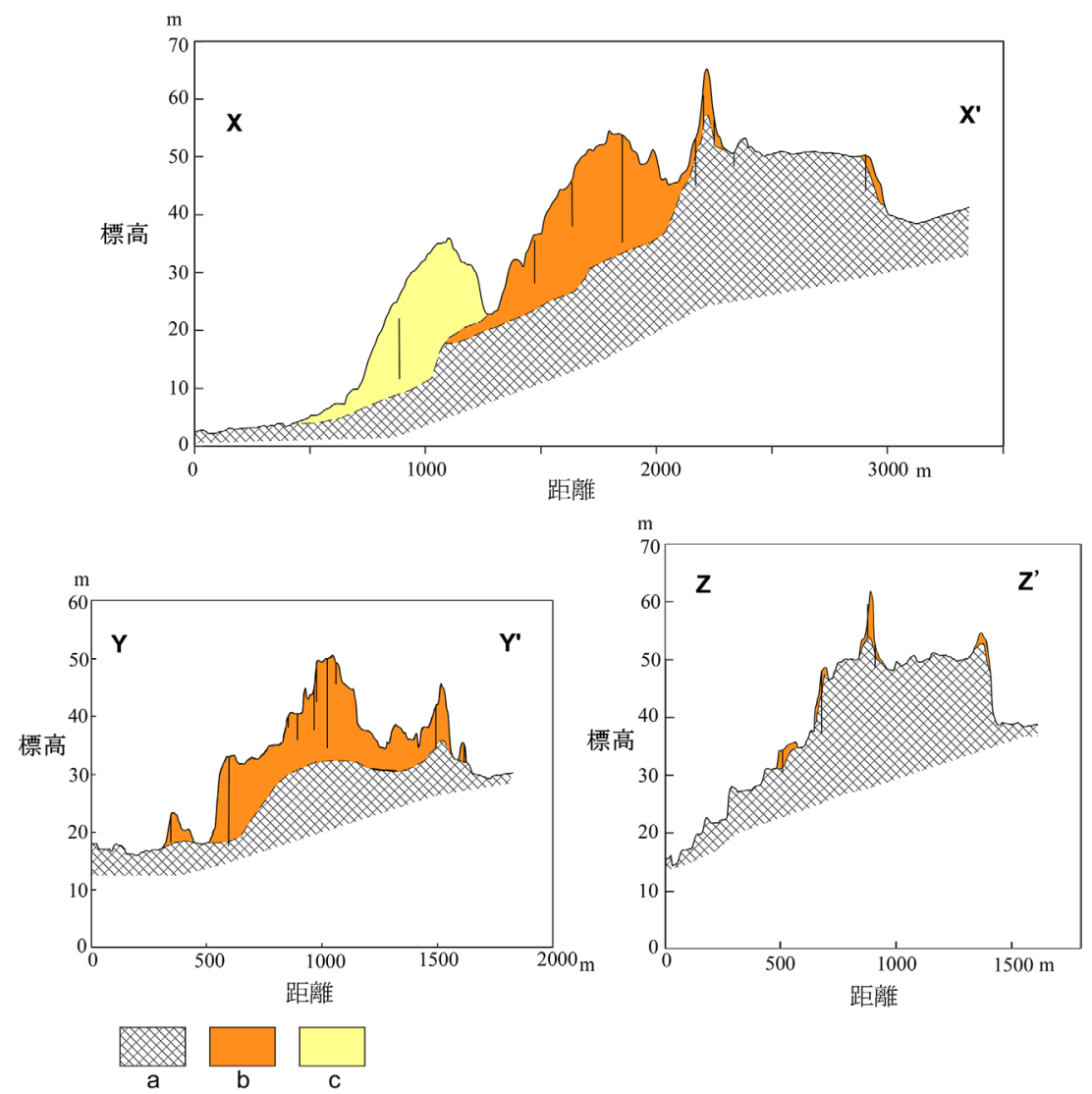

図 8 喜界島南西部の砂丘地帯の地形地質断面図. $\mathrm{a}$ ：サンゴ石灰岩, $\mathrm{b}$ : 更新世砂丘堆積物, $\mathrm{c}$ : 完新世砂丘堆積物, 断面位置は図 1 参照.

Fig. 8 Geomorphic and geologic profiles in the sand dune area at the southwestern part of Kikaijima. a: Coral limestone, b: Pleistocene sand dune deposit, c: Holocene sand dune deposit, See Fig. 1 for positions of profiles.

\section{2) 砂丘堆積物}

\section{2-1）水天宮砂丘地帯}

この地帯の砂丘の主要部は, 最大 $20 \mathrm{~m}$ 以上に 及ぶ厚い砂丘堆積物からなる（図 $3,7,8$ )。 砂丘堆積物のなかには少なくとも 2 層の埋没古 土壤が挟まれる。加えて古砂丘に覆われ，基盤の 段丘堆積物の頂面に形成された古土壤が存在する (図 3 )。これらの古土㙵を, 上位から, 上位埋

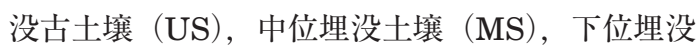
古土壤 (LS) と呼んでおく。これら 3 層の古土 壌は成瀬・井上（1987）が認めたものに相当す ると考えられる。砂丘堆積物中の上位・中位の 2 層の古土壤は, 水天宮砂丘地帯北部において砂丘
形成の 2 回の中断を挟む砂丘形成期が少なくと も 3 回あったことを示す。

砂丘堆積物は場所によって程度はさまざまであ るが，固結し，岩石のように固くなっている。こ のような固結した砂丘堆積物と砂丘は砂板（武永, 1968), Dune-rock（能勢, 1971），こう結砂丘 （成瀬・井上, 1987）などと呼ばれている。こう 結しているところでは，明瞭に識別できる層理が 認められる（図 7 )。レンズ状のラミナもあるが, 平行層理が主体である。その厚さは一般には数 $\mathrm{cm}$ で，下位の薄い粗砂層と上位の厚い中・細粒 砂層がセットで 1 つのユニットを形成している。 これがこう結しているため層理の走向・傾斜を比 
較的容易に求めることができる。

いくつかの地点での砂丘堆積物の層理の走向か ら知られる風向は，この砂丘列の方向と基本的に は調和し，砂丘砂が北側の海岸を給源として北方 からの卓越風によって運搬・供給されたことを 示す（図 1 ）。それは成瀬・井上（1987）の指摘 と基本的には整合する。この厚い水天宮砂丘は MIS 3 段丘群最下位の F 面の北端まで続く。上 述の地形の長軸方向と合わせると，この付近の海 浜からの砂の供給によって, 縦列砂丘として内陸 側に堆積していったことを示す。

\section{2-2）赤連砂丘地帯}

砂丘堆積物は，淘汰のよい中粒砂からなり，そ のうちの No. 20 地点では, 砂丘堆積物の厚さは $6 \mathrm{~m}$ 以上あり，その層理の走向から知られる風向 もほぼ地形の長軸方向と調和する（図 1 ）。

\section{3）砂丘の編年}

\section{3-1）海成段丘との関係}

上記のように喜界島南西部の更新世砂丘は，段 丘面の示す当時の海岸沿いに平行に形成された小 規模な横列砂丘と, 水天宮砂丘地帯北部・赤連砂 丘地帯の比較的大規模な縦列砂丘からなる。

水天宮砂丘地带南部の横列砂丘は，最上位の $\mathrm{D}$ 段丘面から下位の $\mathrm{E} ， \mathrm{~F}$ 段丘面にわたって存在 する。これらの段丘面形成時の海浜形成と離水に 伴って，当時の海浜や下位の段丘面の海岸に沿っ て徐々に形成されており（図 $1 ， 3$ ），こうした 段丘面あるいは直下の段丘面崖端の海浜と同時期 のものとみることができる。サンゴ礁段丘のサン ゴ試料から測定された多くのウラン系列年代（稲 垣ほか, 2005） と MIS 3 の海面変化（Lambeck et al., 2002; Siddall et al., 2003) は，D，E，F 段丘面群にのる水天宮砂丘地带の砂丘は MIS 3 の高海面期に形成されたことを示す。 E， F 面上 にのる水天宮砂丘地帯北部・赤連砂丘地帯の砂丘 は，F 面末端にまで分布することから，段丘面と の関係からは MIS 3 後半の高海面期に対応して 形成されたことが示唆される。これまでも更新世 の最低位段丘形成末期に形成されていることが指 摘されている（武永, 1968）。

\section{3-2）テフラとの関係}

喜界島で見いだされた上記テフラのうち，水天 宮砂丘地带北部の砂丘を覆うもっとも古いテフラ はATである（図 3 ）。それは砂丘間の凹地を埋 積した土袞中に保存されている（図 4 ）。AT と 砂丘砂との間には，埋没凹地中の位置によって異 なるが, 数 $10 \mathrm{~cm}$ の厚さの土壤が堆積している。 このことから，砂丘の形成が終わったのは，AT の降下年代 (30,000 cal BP ; Smith et al., 2013) より若干前と考えられる。ATょり下位のテフラ (Kj-7）はここでは認められない。

\section{3-3） ${ }^{14} \mathrm{C}$ 年代との関係}

水天宮砂丘地帯北部の No. 11 地点において上 位埋没土壤と中位埋没土壤の間の砂層と, これ と同層準とみられる No.4 地点の砂層から得られ た陸成巻貝 ${ }^{14} \mathrm{C}$ 年代は，それぞれ $33,260 \mathrm{cal} \mathrm{BP}$ (No. 11-2))，33,771 cal BP (No. 4-1)) で, AT の層位と整合した值を示す（図 3，7，表 4 ）。 陸成巻貝については ${ }^{14} \mathrm{C}$ 年代異常の存在が指摘さ れているが，更新世の試料の場合は，測定誤差内 にとどまるとされている（高橋・和田, 1998）。 これららの ${ }^{14} \mathrm{C}$ 年代は上位にある $\mathrm{AT} の$ 層位と も整合しているので，この年代は妥当な值を示 していると考えられる。一方，No. 11 地点の上 位埋没土䁃（No. 11-1））と中位埋没土䁃（No. 11-3)）の試料について測定された值は，上位の $\mathrm{AT} の$ 年代よりも新しく，陸成巻貝の值とも整合 しないし，上下も逆転している（表 4 ）。ここで は腐植の成熟度が低く，また新しい植物根などが 混入したことによるものとみられる。これまで, 水天宮砂丘地帯からいくつかの陸成巻貝の ${ }^{14} \mathrm{C}$ 年 代が得られてきた（表 4 ; 成瀬・井上, 1987; 高橋· 和田, 1998)。それらの年代は $28,000 ３ 5,000$ ${ }^{14} \mathrm{C} \mathrm{BP}$ を示す。これらの ${ }^{14} \mathrm{C}$ 年代は較正暦年代 ではないが，今回得られた年代や $\mathrm{AT}$ の年代と基 本的には整合する。

以上の段丘面，テフラ， ${ }^{14} \mathrm{C}$ 年代と砂丘との層 位・年代関係から，水天宮砂丘地帯北部の中・上 部砂丘堆積物の形成は $3.2 \sim 3.5$ 万年前ごろと考 えられる。さらに今回得た古土㙥間の砂丘の ${ }^{14} \mathrm{C}$ 年代から上位埋没土䁃は 3.4 万年前より新しく, 
中位埋没土壌はこれより古いと考えられる。

\section{3-4）水天宮砂丘地帯北部の砂丘形成開始}

北部地区の砂丘の北西縁付近にある No. 7 地点 では, 砂丘砂に覆われた $\mathrm{F}$ 段丘堆積物最上部の サンゴ片について， $42,800 \mathrm{cal} \mathrm{BP} の{ }^{14} \mathrm{C}$ 年代が 得られた（図 3, 表 4 )。稲垣ほか（2005）によっ て F 面段丘上で得られた多くのサンゴのウラン 系列年代のうち，もっとも若い年代は 4.1 万年前 を示す。これが $\mathrm{F}$ 面離水年代に近い值であると みられ，それは今回得られた ${ }^{14} \mathrm{C}$ 年代とほぼ整合 する。

No. 7 地点ではこの段丘堆積物と砂丘砂との間 には薄い土袞（下位埋没土壤）があり，段丘離水 後，若干の時間間隙があったことを示す（図 3 )。 この古土壌は, 成瀬・井上（1987）によっても 示されている砂丘砂の下位にある海浜堆積物に形 成された古土壌に相当するとみられる。これらの ことは，F段丘堆積物上に載る更新世砂丘は，こ れより海岸に続き，完新世砂丘によって覆われる $\mathrm{F}$ 面末端より海側にあった海浜から砂が供給され たことを示唆する。

以上のことから，この北部地区の大規模砂丘は， $\mathrm{F}$ 面の縁辺付近にあった 4 万年前ごろの海浜を供 給源として，砂丘形成が開始されたもの考えられ る。 $\mathrm{F}$ 面の海食崖が示すように， $\mathrm{F}$ 面はさらにこ の海食崖より海側にまで進出し， $\mathrm{F}$ 面の海岸を形 成していった。上記の砂丘上部の年代からみる と， 3.2 万年前ごろまで砂丘砂供給源としての海 浜が存在していたものと考えられる。

赤連砂丘地帯では，形成年代にかかわるテフラ や ${ }^{14} \mathrm{C}$ 年代の資料は得られていないが，厚い砂丘 砂が縦列砂丘をなすことや，その形成時期の海浜 を示す位置が水天宮砂丘地帯北部の砂丘と同様の $\mathrm{F}$ 面の縁辺にあるという点からみて，水天宮砂丘 地帯北部の砂丘と同時期の形成と考えられる。

以上から，水天宮砂丘地帯北部と赤連砂丘地帯 の更新世砂丘は $3.2 \sim 4$ 万年前，すなわち MIS 3 の後半に形成されたと考えられる。

\section{VI. 喜界島南西部の砂丘の形成環境}

\section{1）完新世砂丘}

日本列島の完新世海岸砂丘の形成は，一般には およそ $6,000^{14} \mathrm{C}$ 年前以後とされる（遠藤, $1969 ;$ 角田, 1975; Endo, 1986; 成瀬, 1989 ほか)。これ は K-Ahの年代より新しい。南九州の薩摩半島 の吹上浜砂丘地带では, 台地を覆うもっとも古 いとみられる完新世砂丘は K-Ah を覆っている し, 大隅半島の志布志砂丘地帯の砂丘も池田降下 軽石 $(6,400 \mathrm{cal} \mathrm{BP})$ よりも新しい（森脇，未公 表)。このように，日本列島の完新世海岸砂丘は 一般に K-Ahより新しいのは, 最終水期末以降の 海面上昇の高頂期が K-Ah の降下年代のころであ り，このころ以後に砂州など海岸堆積域の陸化が はじまったことによる（遠藤, 1969; Moriwaki, 1982)。一方で，隆起の大きな地域や完新世海進 以前の基盤地形が海岸に迫り，これを直接覆うよ うなところでは，これよりも古い時期にまでその 形成開始がさかのぼる場合もあることが指摘され ている（遠藤, 1969）。

喜界島において，これょり古い時期，海面高頂 期以前に砂丘の形成がみられるのは，喜界島が顕 著な隆起地域にあり（町田ほか, 2001），ょり古 い海面上昇期に相対的に高海面期に近い状態をな し，海岸の離水が比較的早かったためと考えられ る。加えて，喜界島においては，砂丘砂の構成 物質にみられるように (Hanzawa, 1935)，海面 上昇期も海岸にはサンゴや有孔虫などの海岸生物 生産が活発であったため, 海浜砂が豊富に供給さ れたことによると考えられる。喜界島南西部中里 付近の砂丘の海岸側にある完新世海成段丘につい て， 6,500 ${ }^{14} \mathrm{C}$ 年前ごろの年代，つまり K-Ah 降 下期ごろの年代（町田・新井, 1978）が得られて いることは（三位・木越, 1966; Omoto et al., 1976), K-Ah 降下以前の完新世砂丘砂堆積時の 海岸は喜界島弓道場 No. 2 地点に近い位置にあっ たことを示す。それは，上記の K-Ah 降下以前の 砂丘形成が示す海浜がNo. 2 地点の近隣に存在し ていたことと整合する。加えて，更新世砂丘が完 新世段丘と接する $\mathrm{F}$ 面段丘崖まで分布している 

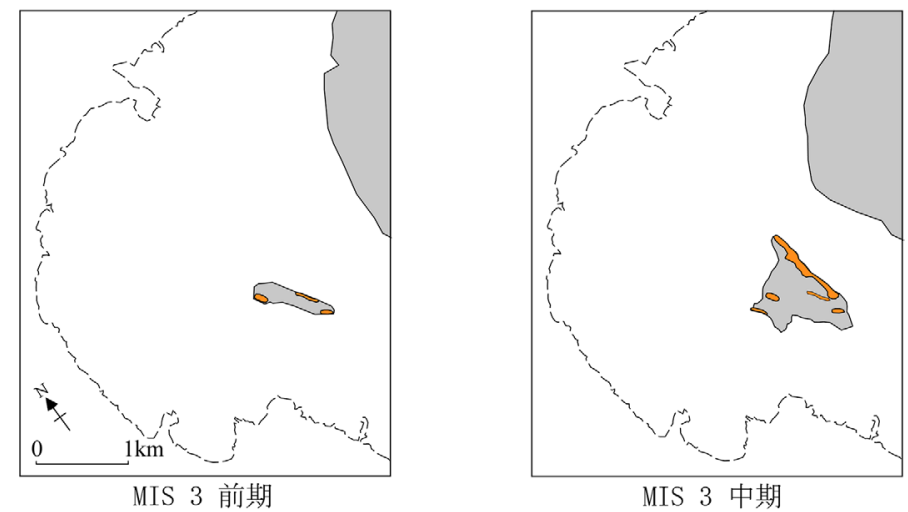

MIS 3 中期
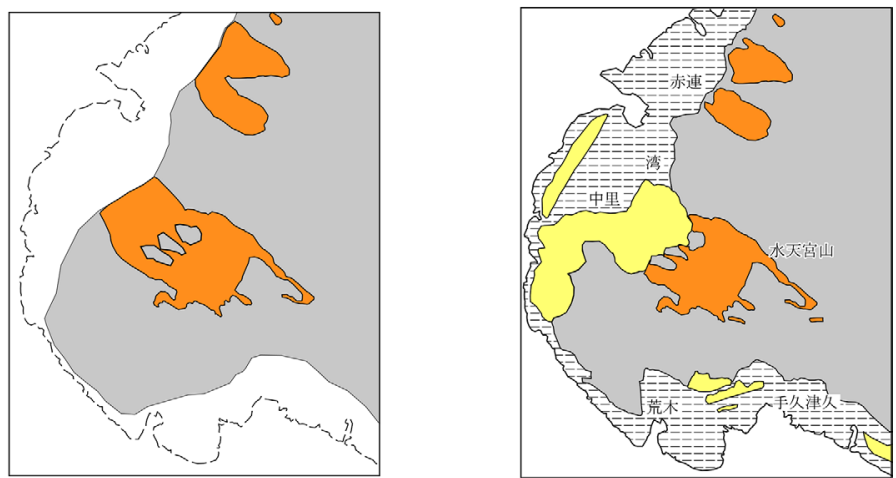

完新世

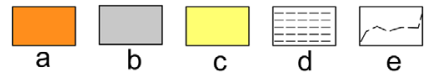

図 9 喜界島南西部の海岸環境と砂丘の古地理変化. $\mathrm{a}$ ：更新世砂丘, b : 更新世段丘, $\mathrm{c}$ ：完新世砂丘, $\mathrm{d}$ ：完新世段 丘・低地, e : 海, 現汀線.

Fig. 9 Palaeogeographic changes in coastal environments and sand dunes at the southwestern part of Kikaijima. a: Pleistocene sand dune, b: Pleistocene terrace, c: Holocene sand dune, d: Holocene terrace, lowland, e: Sea, present shoreline.

ことは，この砂丘が完新世の海進による海岸侵食 を受け，当時の海浜に堆積した砂も完新世の砂丘 形成に寄与していることを示唆する。

$\mathrm{K}-\mathrm{Ah}$ 以前の腐植層が示す砂丘の固定と活動 は，砂丘砂供給源としての海浜の形成に関わる海 岸環境の変化によると考えられるが，詳細は今後 の課題である。喜界島南西部で広く認められる $3,000 \sim 4,500{ }^{14} \mathrm{C}$ 年前頃の腐植層は，全国的に 認められている旧期クロスナ層（遠藤，1969）に 対比されるとみられる。南九州, 大隅半島東岸の 志布志砂丘では，弥生時代中期～弥生時代終末期 の住居趾を含むクロスナ層が，その後の古墳時代
以降の砂丘砂によって覆われている (Ngasako, 2001; 大崎町教育委員会, 2006)。こうした点は, この時期の砂丘の固定に, 縄文後期から弥生期に かけての海面変化や気候変化など広域に共通する 環境変化が関わっていることを示唆する。

\section{2) 更新世砂丘}

\section{2-1）海岸環境との関係}

上記の諸点から，砂丘形成に関わる海岸環境の 変化と編年を図 $9 ， 10$ のように描くことができ る。MIS 3 前期には，百之台を中心とする陸域 の南側の海域で，サンゴ礁が陸化した。この小島 に形成された砂浜海岸の背後に小規模な横列海岸 


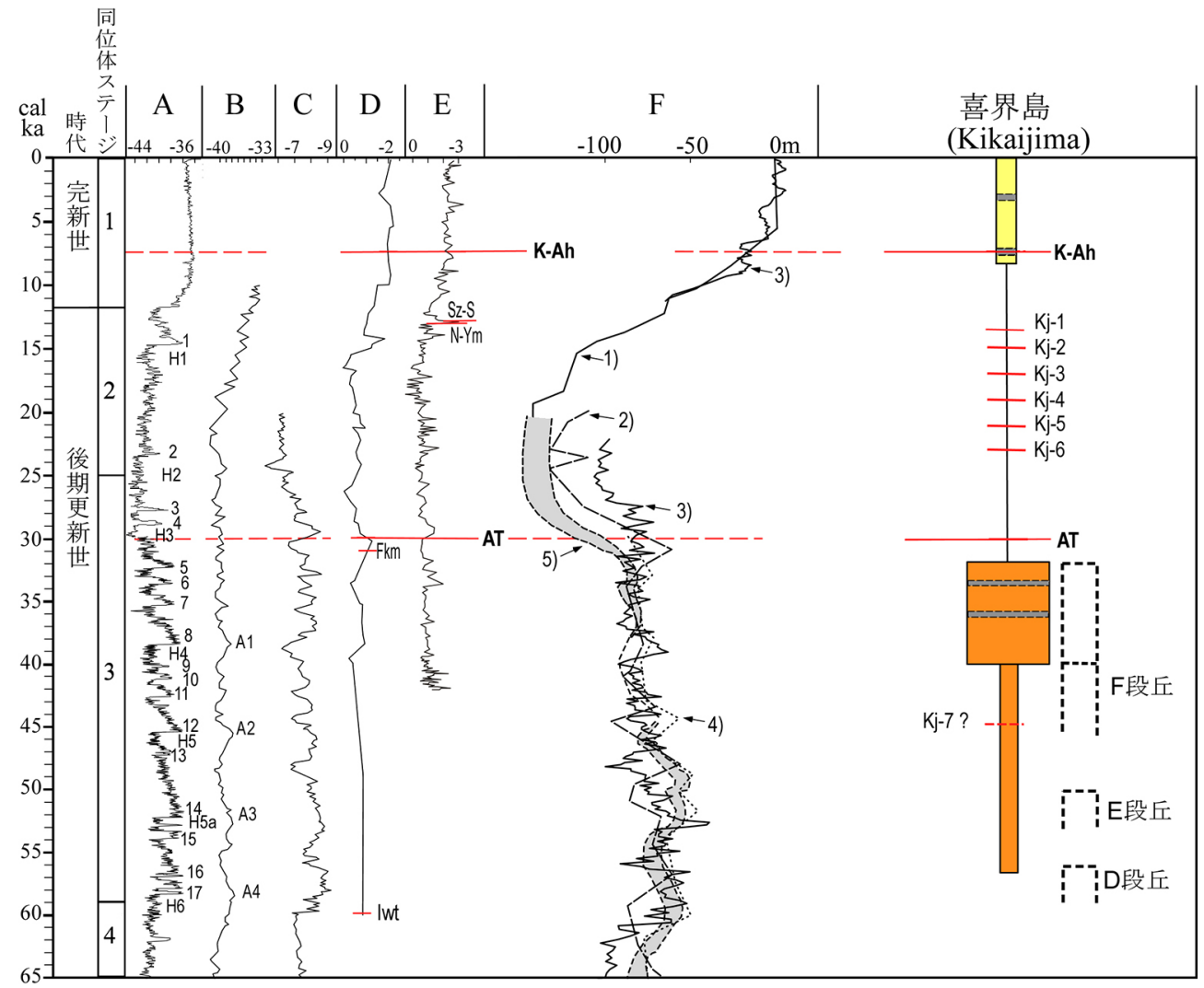

図 10 喜界島の砂丘編年と気候変化・海面変化の関係. 喜界島：黄色，橙色はそれぞれ完新世，更新世の砂丘形成 期，幅は相対的規模，赤色線はテフラ層位. $\mathrm{A} \sim \mathrm{E}$ ：酸素同位体記録， $\delta^{18} \mathrm{O}(\%), \mathrm{A}:$ 水床コア，グリーンラ ンドNGRIP, GICC05 (Lowe et al., 2008), 番号は D-O warming event (Dansgaard et al., 1993; Dokken et al., 2013), H1 〜 H6 は Heinrich event (Bond and Lotti, 1995; Rashid and Hesse, 2003) による. B : 水床コア, 南極 Byrd, A1 A4; Antarctica warm events (Blunier and Brook, 2001), C : 石简, 中国 Hulu (Wang et al., 2001), D : 海底コア，四国沖 MD012422（池原ほか, 2006), E ：海底コア，東シナ海北部 MD982195（Ijiri et al., 2005), Sz-S と N-Ym のテフラ層位は Moriwaki et al. (2016) による. F:海面変化;1）Yokoyama et al. (2007), 2) Thompson and Goldstein (2006), 3) Siddall et al. (2003), 4) Chappell (2002), 5) Lambeck et al. (2002).

Fig. 10 Chronology of sand dunes in Kikaijima and its relations to climatic and sea-level changes. Column of Kikaijima: Yellow and orange patterns denote the stage of the formation of Holocene and Pleistocene sand dunes respectively, and its width, relative sizes of sand dunes, and red line, stratigraphic position of marker tephra. A-E: Oxygen isotope records $\delta^{18} \mathrm{O}(\%)$. A: Greenland ice core NGRIP, GICC05 (Lowe et al., 2008). Numbers denote D-O warming events (Dansgaard et al., 1993; Dokken et al., 2013), H1-H6, Heinrich event (Bond and Lotti, 1995; Rashid and Hesse, 2003). B: Antarctica ice core Byrd, A1-A4; Antarctica warm events (Blunier and Brook, 2001). C: Stalagmite, Hulu, China (Wang et al., 2001). D: Marine core, MD012422, off Shikoku (Ikehara et al., 2006). E: Marine core, MD982195, northern part of the East China Sea (Ijiri et al., 2005), after Moriwaki et al. (2016) for the stratigraphic positions of Sz-S and N-Ym tephras. F: Sea-level change; 1) Yokoyama et al. (2007), 2) Thompson and Goldstein (2006), 3) Siddall et al. (2003), 4) Chappell (2002), 5) Lambeck et al. (2002).

砂丘が形成された。隆起に伴い，この小島は段丘 と海岸沿いに砂丘をつくりながら拡大していった (MIS 3 中期)。MIS 3 後期には，百之台を中心 とする陸域と水天宮砂丘地帯の陸域との間にある
海域は離水が進行し，陸化した。そして，中里か ら湾・赤連にかけての喜界島南西部北岸域に, 豊 富な砂丘砂の供給場となる砂浜海岸が形成され, ここを供給源として大規模な砂丘が形成された。 
完新世の高海面期にはほぼ全島を取りまいて海岸 砂丘が形成された。MIS 3 の大規模海岸砂丘の 海岸とほぼ同じ場所に，とくに規模の大きい砂丘 が形成された。

一連の古地理変化は，海岸砂丘形成にとって， 堆積物供給源としての砂浜海岸の形成が第一義的 に重要であることを示す。A，B，C段丘面の分 布（太田・大村, 2000; Moriwaki, 2016）から明 らかなように，MIS 5e，5c，5a の最終間水期の 高海面期には島の規模が小さかったため，砂丘 形成に十分な砂浜海岸が形成されなかった。MIS 3 初期の D 段丘面形成になって，南西部の小島 に砂丘が形成されはじめたが，北側には，MIS 3 の $\mathrm{D} ， \mathrm{E} ， \mathrm{~F}$ 面が形成されたにもかかわらず，砂 丘が形成されなかったのは，海況環境などにより 顕著な砂浜海岸の形成がなかったことによると考 えられる。

現在の水天宮砂丘地帯周辺には， E， F 段丘堆 積物最上部にサンゴ礫を含む比較的厚い砂堆積物 が認められ，浜堤や砂州を形成している。Hanzawa（1935）は喜界島南西部の北岸沿いの MIS 3 面（F 面）に，砂を含む砂礫層（国頭礫層）を 広く認めているし，また三位・木越（1966），斎 藤ほか（1972）も海浜砂の存在を指摘している。 このことは，F 面形成期には，砂丘砂の供給源と なる海浜砂が南西部に広く存在していたことを示 す。水天宮砂丘地帯・赤連砂丘地帯の大規模な砂 丘の形成は，第一義的には，隆起による陸地の拡 大に伴って, $\mathrm{F}$ 面形成の MIS 3 後半に周辺海岸 などから豊富な海浜砂が生産・集積しやすい海岸 環境が形成され，これによって砂丘砂供給源とし ての砂浜海岸が形成されたことによるものと考え られる。

喜界島南西部の水天宮・赤連砂丘地帯の大規模 な砂丘は，氷期の形成としては特異な形成期をも ち（三位・木越, 1966; 成瀬・井上, 1987)，その 形成環境には氷期の乾燥・強風の気候環境が関 わっていることが指摘された（三位，1965）。一 方，成瀬・井上（1987）は，砂丘が水期に形成さ れた石灰岩上に載ることから，砂丘の形成が隆起 の激しい地域でみられる特徵的な現象である可能
性を示唆している。今回の結果は，基本的には成 瀬・井上（1987）のこの指摘を支持している。 しかしこの報告では，当時の水期・間水期という 大枠での知見から，水天宮砂丘の形成は氷期の形 成という気候環境によることが示唆されている。 上記のように，この砂丘は，氷期のなかでも亜間 水期の高海面期（ $\mathrm{F}$ 面形成期）に対応した形成, すなわち MIS 3 後期の高海面期に対応して形成 され，これが隆起により現在の陸上に残されたも のである。完新世（間水期，MIS 1）の砂丘が存 在していることからみても, 水天宮砂丘地帯の MIS 3 の砂丘の存在は，第一義的には，水期特 有の形成環境によるものというよりも，高海面期 に対応した海岸環境によるとみた方がより適切で あろう。一方，後述の気候変化との関係のところ で検討しているように，水天宮砂丘地帯の MIS 3 後期の砂丘の大規模化は，完新世よりも強い乾 燥と風の気候環境が関与していることが推定され る。

\section{2-2）海面変化との関係}

異なる方法で求められた氷床量変化に対応す るいくつかの海面変化曲線について, MIS 3 の 時期に共通していることは，20〜 $30 \mathrm{~m}$ の規模 で 4 回の上下変動があり，海水準は全体として 前半は $-60 \mathrm{~m}$, 後半は $-80 \mathrm{~m}$ に下がったという 点である（図 10 ; Siddall et al., 2008）。喜界島 南西部の大規模な水天宮・赤連砂丘の形成は, 形成年代（3.2〜 万年前）からいえば，MIS 3 最新の高海面期（3.9 3.8 万年前から $3 \sim 2.7$ 万年前；Chappell, 2002; Lambeck et al., 2002; Thompson and Goldstein, 2006; Siddall et al., 2003）に対応している。

日本列島では，OSL 年代から特定された MIS 3 前期の海岸砂丘が鳥取砂丘地帯で認められてい る (Tamura et al., 2001)。喜界島と共通するこ とは，その基本的な形成は，気候変化によるもの ではなく，MIS 3 の高海面期の海岸からの砂丘 砂供給によるものであることである。細かくみる とその形成期は喜界島の水天宮・赤連地区の大規 模砂丘のそれ（MIS 3 後期）とずれる。それは, 次のような，砂丘砂の供給源と運搬距離，その場 
所の隆起という点から検討が可能である。上記の ように，喜界島の水天宮・赤連地区の大規模砂丘 は，砂丘砂供給源としての海浜砂の生産・堆積量 がMIS 3 後期に多大となって形成され，これが 隆起により現在の陸上に出現した。一方，鳥取砂 丘地带の MIS 3 前期の砂丘形成については, 上 記の MIS 3 前・後期の海面位置から知られるよ うに，相対的に海面の低い MIS 3 後期の海岸は 砂丘砂が到達できる限界距離以上のところに存在 したのに対し，よりの海面の高い MIS 3 前期の 海岸は, 砂丘砂が現在の砂丘地帯に到達できる距 離にあったことによる（Tamura et al., 2001）。

\section{2-3) 気候変化との関係}

前記のように喜界島南部の水天宮・赤連地区の 大規模砂丘は，海岸側にある完新世砂丘とは形態 が異なり，全体として北西-南東方向に長軸をも ち，さらにそのなかの主要な尾根筋とこれと同時 期に形成された谷筋も同様の方向をもち，砂丘砂 層の層理の走向もこの方向の風向を示すことは, この砂丘が縦列砂丘であることを示す。北九州の 沿岸では，最終水期には縦列砂丘が形成されてい る（成瀬, 1976)。鳥取海岸では MIS 3 において, 当時の海浜から $5 \mathrm{~km}$ 内陸にあたる現在の海岸地 帯に砂丘砂が到達したとされる（Tamura et al., 2001）。それは縦列砂丘の存在を示唆し，喜界島 での結果と符合している。縦列砂丘は, 砂丘地形 のなかでももっとも強い風によってつくられると される（貝塚, 1998）。このことは，完新世中 · 後期の砂丘形成の時期に比べれば，より寒冷な気 候下にあるMIS 3 の時期において，より強い風 が卓越していたことを示唆している。大陸の大規 模な内陸砂丘地帯では, MIS 3 において強風・乾 燥によって広く砂丘が活動したことが指摘されて いる (Fitzsimmons et al., 2007; 遠藤, 2017)。 以上の諸点は，喜界島の水天宮砂丘形成について は，上記した大規模化とともに，形態においても MIS 3 の強風・乾燥の気候環境が関わっている ことを示唆している。

水天宮・赤連地区の大規模砂丘の砂丘堆積物の なかに挟まれる古土壌は，寒冷期に中国大陸から の風成塵の降下・堆積によって形成されたとされ
る（成瀬・井上, 1987）。今回の編年からすると, 全体的には古土壤を含む砂丘堆積物は，上記のよ うにMIS 3 の 4 回の海面の上下変動のうち，お よそ 4 万年前から 3 万年前の最新の高海面期に あたる。詳しくみるとこの時期には細かな海面の 上下変動がある（図 10）。気候的には，この時期 には D-O warming events $5 〜 8$ とこれに挟まれ た寒冷期がある（図 10 ; Dokken et al., 2013)。 この変化に, 喜界島に近い中国大陸の鍾乳石の酸 素同位体変化がよく対応しているとされ（Wang et al., 2001), 喜界島もこうしたイベントと関わっ ていることが予想される。このことから，喜界島 の古土壤の形成が寒冷期形成（成瀬・井上, 1987) とすると, 古土壤の形成は D-O イベントの間の 寒冷期に対応し，上記のように高海面期に形成さ れたと考えられる砂丘の形成期は，D-O warming events $5 \sim 8$ の温暖期に対応しているとみる こともできる。

一方で, MIS 3 の海面変化 (水床変化) はグ リーンランド氷床コアの気候シグナルょりも，こ れと温暖寒冷がシーソー関係で変化した南極の気 候シグナルに対応しており，MIS 3 の高海面は南 極の温暖シグナルつまり北半球の寒冷シグナルに 対応しているとする見解もある (Siddall et al., 2008)。そうなると, 水天宮砂丘地帯・赤連砂丘 地帯の大規模な砂丘の形成は, 北半球の D-O サ イクルの寒冷イベントに対応し, 古土袞形成と夕 イミングは同じということになる。

グローバルな気候変化と海面変化は, 解決すべ き課題が残されているが，これをさらに深化させ る重要な点の 1 つは年代・対比・編年の高確度化 である（Siddall et al., 2008）。喜界島を含む南 西諸島の砂丘・古土畩編年のさらなる高確度化・ 高精度化は，こうした広域で詳細な気候変化・海 面変化との対応関係を深化させる上で，今後興味 ある課題を提供する。

\section{VII. ま と め}

後期更新世以降の顕著な隆起サンゴ礁段丘から なる喜界島は, 現在より数 $10 \mathrm{~m}$ 低かった MIS 3 の時期の海岸砂丘が陸上でみられる特異なところ 
である。加えて，完新世（MIS 1）の砂丘が近接 して共在し, 異なる環境下で形成された砂丘の形 成環境を比較検討する上で好条件をもっている。 テフラ, ${ }^{14} \mathrm{C}$ 年代資料など砂丘の編年資料も比較 的豊富に得ることができる。今回，喜界島南西部 において完新世・更新世砂丘の分布と構造を明ら かにし，これをテフラ， ${ }^{14} \mathrm{C}$ 年代，サンゴ礁段丘 との関係から編年し，その形成環境を検討した。

$\mathrm{K}-\mathrm{Ah}, \mathrm{AT}$ の広域テフラを含む 9 層のテフラ が見いだされた。 Kj-1〜 Kj-7 と名づけた他の 7 層の細粒テフラは, 今回新しく見いだしたもので, $\mathrm{AT}$ の下位に 1 層, $\mathrm{AT}$ と K-Ah の間に 6 層ある。 それらは，トカラ列島の諸火山に由来するとみら れる。上位 6 層のテフラの年代は 13,000 年前か ら 30,000 年前の間に入る。

完新世の砂丘は, K-Ah 降下以前のおよそ 8,000 年前の海進最盛期前に形成を開始した。それは喜 界島が隆起域で，海岸の離水が海進最盛期以前に はじまったことと, サンゴや有孔虫など南西諸島 以南特有の石灰質海浜砂の生産が高かったためと みられる。

喜界島南西部の水天宮砂丘地帯と赤連砂丘地帯 における更新世砂丘の詳しい分布と構造の知見か らみると, この地帯の砂丘は, 水天宮砂丘地帯南 部の小規模な横列砂丘と, 水天宮砂丘地帯北部 赤連砂丘地带の大規模な縦列砂丘からなる。南部 の横列砂丘は, MIS 3 の高位の面から隆起によ る離水に伴って, 小規模な海岸砂丘として形成さ れていった。水天宮砂丘地帯北部と赤連砂丘地帯 において, MIS 3 の段丘面でも最下位の面に分 布する大規模な砂丘は, MIS 3 後期の 4 万年前 から 3.2 万年前に形成された。

編年の詳細が明らかな喜界島全体の海成段丘面 と砂丘形成との関係は, 砂丘の形成には砂丘砂供 給源としての砂浜海岸の存否が第一義的に関わっ ていることを示す。更新世砂丘の編年は，砂丘形 成が海況変化に影響した MIS 3 の海面変化のう ち少なくとも 4 回の高海面期と関わっていること を示唆する。一方, 水天宮砂丘地帯北部と赤連砂 丘地帯の大規模な砂丘は縦列砂丘の形態を示し, 完新世の砂丘とは異なる。こうした砂丘の規模と
形態は，完新世より寒冷な MIS 3 の時期の卓越 風の強さを反映しているとみられる。

MIS 3 の海岸砂丘形成は, MIS 3 の細かな海 面変化 (Lambeck et al., 2002; Siddall et al., 2003）と関わっていると推定される。喜界島は, 砂丘と埋没土壤を含む堆積物の精度のよい編年を 行える環境にあり，さらに細分可能な MIS 3 段 丘面群が存在し, MIS 3 の細かな海面変化・海 岸環境変化と砂丘形成の関係を検討できる潜在的 な条件を備えている。その解明は, 東アジアの気 候変化やグローバルな海面変化と，これに影響を 受けた海岸環境・気候環境の変化に伴う砂丘形成 との関係について, より高確度・高精度の解明を 促進するであろう。テフラはその際の重要な編年 資料の 1 つなりうる。今回の報告は, 砂丘の 編年を, 近隣の海底コアの酸素同位体の変化とテ フラによってリンクさせ，さらに，これと中国大 陸の洞窟などで得られている気候変化, そして氷 床コアなどグローバルな高分解能気候変化，海面 変化とリンクさせることによって，砂丘形成と環 境変化との関係が高精度で検討可能な展望を開く ことができたと考える。南九州・南西諸島におい て，テフラをもとにした後期更新世以降のさまざ まな古環境・文化諸要素の高精度編年を統合し, それらの相互関係が検討されている（Moriwaki et al., 2016)。本報告の結果は，その一環として 位置づけることができる。

\section{謝 辞}

国立極地研究所の三浦英樹准教授には海面変化につ いて, 田上善夫富山大学名誉教授には気候環境につい て教示を受けた。元喜界町教育委員会の澄田直敏氏に はテフラを提供していただいた。松原信之氏をはじめ とする喜界町埋蔵文化財センターの方々には，現地調 査，文献などさまざまな教示・便宜を受けた。David J. Lowe ワイカト大学教授には英文をみていただいた。遠 藤邦彦日本大学名誉教授には砂丘形成に関する文献情 報と教示を受けた。查読者には有益なコメントをいた だいた。本研究には $2018 ２ 020$ 年度科学研究費補助 金（基盤研究 (C), 課題番号 18K01122）を使用した。 深く感謝いたします。 


\section{文献}

Blunier, T. and Brook, E. (2001): Timing of millennialscale climate change in Antarctica and Greenland during the last glacial period. Science, 291, 109-112.

Bond, G.C. and Lotti, R. (1995): Iceberg discharges into the North Atlantic on millennial time scales during the last glaciation. Science, 267, 1005-1010.

Chappell, J. (2002) : Sea level changes forced ice breakouts in the Last Glacial Cycle: New results from coral terraces. Quaternary Science Reviews, 21, 1229-1240.

Dansgaard, W., Johnsen, S.J., Clausen, H.B., DahlJensen, D., Gundestrup, N.S. Hammer, C.U., Hvldberg, C.S., Steffensen, J.P., Sveinbjomsdottir, A.E., Jouzel, J. and Bond, G. (1993): Evidence for general instability of past climate from a 250 -kyr icecore record. Nature, 364, 218-220.

Dokken, T.M., Nisancioglu, K.H., Li, C., Battisti, D.S. and Kissel, C. (2013): Dansgaard-Oeschger cycles: Interactions between ocean and sea ice intrinsic to the Nordic seas. Paleocenogaraphy, 28, 491-502.

遠藤邦彦（1969）：日本における沖積世の砂丘の形成 について. 地理学評論, 42, 159-162. [Endo, K. (1969): The formation and fixing of Holocene sand dunes in Japan. Geographical Review of Japan, 42, 159-162. (in Japanese with English abstract)]

Endo, K. (1986): Coastal sand dunes in Japan. Proceedings of the Institute of Natural Sciences, College of Humanities and Sciences, Nihon University, Earth Sciences, 21, 37-54.

遠藤邦彦 (2017): 古地形・堆積物からさぐる古気候・ 環境変遷。山川修治. 常盤勝美・渡来 靖編 : 気候変 動の事典. 朝倉書店，366-375. [Endo, K. (2017)： Paleoclimate environmental evolution in geomorphic processes and sediments. in Encyclopedia of Climatic Variations edited by Yamakawa, S., Tokiwa, K. and Watarai, Y., Asakura Shoten, 366375. (in Japanese)*]

Fitzsimmons, K.E., Rhodes, E.J., Magee, J.W. and Barrows, T.T. (2007): The timing of linear dune activity in the Strzelecki and Tirari Deserts, Australia. Quaternary Science Reviews, 26, 2598-2616.

Hanzawa, S. (1935): Topography and geology of the Riukyu Islands. Science Reports of the Tohoku Imperial University, 2nd Series, 17, 1-61.

Ijiri, A., Wang, L., Oba, T., Kawahata, H., Huang, C.-Y. and Huan, C.-Y. (2005): Paleoenvironmental changes in the northern area of the East China Sea during the past 42,000 years. Palaeogeography, $\mathrm{Pa}$ laeoclimatology, Palaeoecology, 219, 239-261.

池原 実・村山雅史・多田井 修. 外西奈津美 - 大道 修宏・川幡穂高・安田尚登 (2006) : 四国沖から採取 された 2 本の IMAGES コアを用いた第四紀後期にお けるテフラ層序. 化石, 79, 60-76. [Ikehara, M., Murayama, M., Tadai, O., Hokanishi, N., Daido, N., Kawahata, H. and Yasuda, H. (2006): Late Qua- ternary tephrochronology of two IMAGES cores taken from the off Shikoku in the Northwest Pacific. Fossils, the Palaeontological Society of Japan, 79, 60-76. (in Japanese with English abstract) ]

稲垣美幸 - 大村明雄 - 八木洋江 - 加藤道雄 (2005): 喜界島に分布する後期更新世最下位段丘構成物の堆 積年代. 第四紀研究，44，93-106. [Inagaki, M., Omura, A., Yagi, H. and Kato, M. (2005): U-series ages of Carbonate sediments underlying the lowest marine terrace of the upper Pleistocene in Kikai Island, central Ryukyus, Japan. Quaternary Research (Daiyonki-Kenkyu), 44, 93-106. (in Japanese with English abstract)]

貝塚爽平 (1998): 発達史地形学. 東京大学出版会.

[Kaizuka, S. (1998): Historical Geomorphology. University of Tokyo Press. (in Japanese) ]

Kitagawa, H., Fukusawa, H., Nakamura, T., Okamura, M., Takemura, K., Hayashida, A. and Yasuda, Y. (1995): $\mathrm{AMS}{ }^{14} \mathrm{C}$ dating of the varved sediments from Lake Suigetsu, central Japan and atmospheric ${ }^{14} \mathrm{C}$ change during the late Pleistocene. Radiocarbon, 37, 371-331.

小林哲夫 (2013)：徳之島に分布する火山灰層と津波堆 積物一徳之島における火山災害および津波災害の可 能性一.「南九州から南西諸島における総合的防災研 究の推進と地域防災体制の構築」報告書, 鹿児島大学 地域防災教育研究センター，141-145. [Kobayashi, T. (2013): Volcanic ash layers and tsunami deposits in Tokunoshima-Potential of vocanic and tshumani disasters in Tokunoshima- Reports on the Construction of Resional System for Natural Hazards and Promotion of the Comprehensive Study on the Natural Hazards in Southern Kyushu and Nansei Islands (Minami Kyushu Kara Nansei Shoto Ni Okeru Sogoteki Bosai Kenkyu No Suishin To Chiiki Bosai Taisei No Kochiku Hokokusho), Research and Education Center for Natural Hazards, Kagoshima University, 141-145. (in Japanese)*]

Konishi, K., Omura, A. and Nakamichi, O. (1974): Radiometric coral ages and sea level records from the late Quaternary reef complexes of the Ryukyu Islands. Proceedings of the Second International Coral Reef Symposium, Australia, 595-613.

Lambeck, K., Yokoyama, Y. and Purcell, T. (2002): Into and out of the Last Glacial Maximum: Sealevel change during oxygen isotope stages 3 and 2 . Quaternary Science Reviews, 21, 343-360.

Lowe, J.J., Rasmussen, S.O., Björck, S., Hoek, W.Z., Steffensen, J.P., Walker, M.J.C., Yu, Z.C. and INTIMATE Group (2008): Synchronization of palaeoenvironmental events in the North Atlantic region during the Last termination: a revised protocol recommended by the INTIMATE group. Quaternary Science Reviews, 27, 6-17.

町田 洋・新井房夫 (1978): 南九州鬼界カルデラから 噴出した広域テフラーアカホヤ火山灰. 第四紀研究,

17, 143-163. [Machida, H. and Arai, F. (1978): 
Akahoya ash - A widespread marker erupted from Kikai caldera, southern Kyushu, Japan. Quaternary Research (Daiyonki-Kenkyu), 17, 143-163. (in Japanese with English abstract)]

町田 洋・新井房夫 (2003): 新編火山灰アトラス。東 京大学出版会. [Machida, H. and Arai, F. (2003): Atlas of Tephra in and around of Japan. University of Tokyo Press. (in Japanese)]

町田 洋 - 太田陽子・河名俊男 - 森脇 広 - 長岡信治 (2001): 日本の地形 7 「九州・南西諸島」. 東京大学 出版会. [Machida, H., Ota, Y., Kawana, T., Moriwaki, H. and Nagaoka, S. (2001): Geomorphology of Kyushu and the Ryukyus, Regional Geomorphology of the Japanese Islands, Vol.7. University of Tokyo Press. (in Japanese)]

三位秀夫（1965）：海岸砂丘の形成について，第四紀研 究，4，5-12. [Mii, H. (1965): Development of coatal dunes in Japan. Quaternary Research (DaiyonkiKenkyu), 4, 5-12. (in Japanese with English abstract)]

三位秀夫・木越邦彦（1966）：奄美群島喜界島の旧汀線 堆積物と海岸砂丘の ${ }^{14} \mathrm{C}$ 年代. 地球科学, 82, 43-45.

[Mii, H. and Kigoshi, K. (1966): ${ }^{14} \mathrm{C}$ ages of past shore deposits and coastal sand dune in Kikaijima, Amami Islands. Earth Science (Chikyu Kagaku), 82, 43-45. (in Japanese)*]

Moriwaki, H. (1982): Geomorphic development of Holocene coastal plains in Japan. Geographical Reports of Tokyo Metropolitan University, 17, 1-42.

Moriwaki, H. (2016): Landforms of Kikai-jima island, the Ryukyu Islands with special reference to sand dunes. in The Amami Islands edited by Kawai, K., Terada, R. and Kuwahata, S., Kagoshima University Research Center for the Pacific islands, 90-93.

森脇 広・永迫俊郎・新井房夫 $(2009)$ ：卜カラ列島に おける後期更新世以降のテフラ. 第四紀研究，48, 271-287. [Moriwaki, H., Nagasako, T. and Arai, F. (2009): Late Pleistocene and Holocene tephras in the Tokara Islands, southern Japan. Quaternary Research (Daiyonki-Kenkyu), 48, 271-287. (in Japanese with English abstract) ]

Moriwaki, H., Nakamura, N., Nagasako, T., Lowe, D.J. and Sangawa, T. (2016): The role of tephras in developing a high-precision chronostratigraphy for palaeoenvironmental reconstruction and archaeology in southern Kyushu, Japan, since 30,000 cal. BP: An integration. Quaternary International, 397, 79-92.

Nagaoka, S. (1988): Late Quaternary tephra layers from the caldera volcanoes in and around Kagoshima Bay, southern Kyushu, Japan. Geographical Report of Tokyo Metropolitan University, 23, 49-122.

Nagasako, T. (2001): The geoarchaeology of the Sawame Site of the Shibushi coastal dune, Kyushu Island, Japan, and implications for Japanese history. in Australasian Connections and New Directions: Proceedings of the 7th Australasian Archaeometry
Conference, Research in Anthropolog and Linguistics, 5 edited by Jones, M. and Sheppard, P., 231240.

中川久夫（1969）：奄美群島 徳之島・沖永良部島・与論 島・喜界島の地質 (2). 東北大学理学部地質学古生 物学教室研究邦文報告, 68，1-17. [Nakagawa, H. (1969): Geology of Tokunoshima, Okierabujima, Yoronto and Kikaijima, Amami Gunto, part 2. Contributions from the Institute of Geology and Paleontology Tohoku University, 68, 1-17. (in Japanese with English abstract)]

中田 高・高橋達郎・木庭元晴 (1978)：琉球列島の完 新世離水サンゴ礁地形と海水準変動. 地理学評論,

51, 87-108. [Nakata, T., Takahashi, T. and Koba, M. (1978): Holocene-emerged coral reefs and sealevel changes in the Ryukyu Islands. Geographical Review of Japan, 51, 87-108. (in Japanese with English abstract) ]

成瀬敏郎 (1976): 北九州海岸のヴュルム氷期の砂丘形 成と古土壤. 第四紀研究，15，35-46. [Naruse, T. (1976): A study of the formation of sand dunes and paleosols in the Würm Glacial Age, north Kyushu. Quaternary Research (Daiyonki-Kenkyu), 15, 3546. (in Japanese with English abstract) ]

成瀬敏郎 (1989): 日本の海岸砂丘. 地理学評論, 62, 129-144. [Naruse, T. (1989): Coastal sand dunes in Japan. Geographical Review of Japan, 62, 129144. (in Japanese with English abstract) ]

成瀬敏郎・井上克弘 (1987)：喜界島の石灰質風成砂層 の ${ }^{14} \mathrm{C}$ 年代一日本の第四紀層の ${ }^{14} \mathrm{C}$ 年代 $(164)$ 一.

地球科学, 41, 198-201. [Naruse, T. and Inoue, K. (1989): ${ }^{14} \mathrm{C}$ ages of eolianites in Kikai, Ryukyu Islands $-{ }^{14} \mathrm{C}$ age of the Quaternary deposits in Japan (164) - Earth Science (Chikyu Kagaku), 41, 198-201. (in Japanese) ]

能勢正之（1971）：Dune-Rockについて（第二報）一喜 界島における分布と出現形態—. 鹿児島地理学会紀 要, 19, 81-90. [Nose, M. (1971): Dune-rock (2) -Its distribution and occurrence in Kikaijima. Journal of Geographical Association of Kagoshima, 19, 81-91. (in Japanese)*]

奥野 充・小林哲夫 (1994)：種子島に分布する後期更 新世テフラ. 第四紀研究，33，113-117. [Okuno, M. and Kobayashi, T. (1994): Late Pleistocene tephra layers distributed on Tane Island, southwest Japan. Quaternary Research (Daiyonki-Kenkyu), 33, 113-117. (in Japanese with English abstract) ]

Okuno, M., Torii, M., Naruo, H., Saito-Kokubu, Y. and Kobayashi, T. (2012): AMS ${ }^{14} \mathrm{C}$ dates and major element composition of glass shards of late Pleistocene tephas on Tanegashima Island, southern Japan. Radiocarbon, 54, 351-358.

Omoto, K., Nakata, T. and Koba, M (1976): Tohoku University radiocarbon measurements, IV. Science Reports of the Tohoku University, 7th Series, Geography, 26, 299-310.

大村明雄（1988）：中部琉球喜界島の地史一琉球石灰 
岩サンゴ化石のウラン系列年代測定法のまとめとし て. 地質学論集，29，253-268. [Omura, A. (1988): Geologic history of the Kikai Island, central Ryukyus, Japan: Summary of uranium-series dating of fossil corals from the Riukiu Limstone. Memoirs of the Geological Society of Japan, 29, 253-268. (in Japanese with English abstract)]

大崎町教育委員会 (2006)：大崎町教育委員会発掘調 査報告書 (6)一美堂 $\mathrm{A}$ 遺跡一. 県営農免農道整備事 業（大崎中央 2 期地区）に伴う埋蔵文化財発掘調査 報告書. 44p. [Board of Education of Osaki Town (2006): Report of Archeological Excavation of the Board of Education, Osaki Town (6)-Mido (A) Site-. Archeological Excavation Report for Buried Cultural Remains Associated with Road Construction by Kagoshima Prefecture (Osakicho Kyoiku Iinkai Hakkutsu Chosa Hokokusho 6 Mido A Iseki Kenei Nomen Nodo Seibi Jigyo Osaki Chuo $2 \mathrm{Ki}$ Chiku Ni Tomonau Maizo Bunkazai Hakkutsu Chosa Hokokusho). 44p. (in Japanese)*]

太田陽子・大村明雄 (2000): 南西諸島, 喜界島のサ ンゴ礁段丘の研究小史と問題点. 第四紀研究, $\mathbf{3 9}$,

45-53. [Ota, Y. and Omura, A. (2000): Review of coral reef terrace studies at Kikai Island, Ryukyu Islands, southwestern Japan. Quaternary Research (Daiyonki-Kenkyu), 39, 45-53. (in Japanese with English abstract) ]

太田陽子・町田 洋 - 堀 信行 - 小西健二 · 大村明雄 (1978)：琉球列島喜界島の完新世海成段丘一完新世 海面変化研究へのアプローチ一. 地理学評論, $5 \mathbf{1}$, 109-130. [Ota, Y., Machida, M., Hori, N., Konishi, K. and Omura, A. (1978): Holocene raised coral reefs of Kikai-jima (Ryukyu Islands) - An approach to Holocene sea level study - Geographical Review of Japan, 51, 109-130. (in Japanese with English abstract) ]

太田陽子 - 小池一之 - 鎮西清高 - 野上道夫 - 町田 洋 松田時彦 (2010): 日本列島の地形学. 東京大学出 版会. [Ota, Y., Koike, K., Chinzei, K., Nogami, M. and Matsuda, T. (2010): Geomorphology of the Japanese Islands. University of Tokyo Press. (in Japanese) ]

Rashid, H. and Hesse, R. (2003) : Evidence for an additional Heinrich event between $\mathrm{H} 5$ and $\mathrm{H} 6$ in the Labrador Sea. Paleoceanography, 18, 1007-1021.

斎藤 毅・川口 昇・木庭元晴 (1972): 喜界島の砂丘 について. 鹿児島地理学会紀要，20，55-61. [Saito, T., Kawaguchi, N. and Koba, M. (1972): Sand dunes in Kikaijima. Journal of Geographical Association of Kagoshima, 20, 55-61. (in Japanese)*]

Siddall, M., Rohling, E.J., Almogi-Labin, A., Hemleben, C., Meischner, D., Schmelzer, I. and Smeed, D.A. (2003): Sea-level fluctuations during the last glacial cycle. Nature, 423, 853-858.

Siddall, M., Rohling, E.J., Thompson, W.G. and Waelbroeck, C. (2008): Marine Isotope Stage 3 sea level fluctuations: Data synthesis and new outlook. $R e$ - views of Geophysics, 46, 1-29.

Smith, V.C., Staff, R.A., Blockley, S.P.E., Bronk Ramsey, C., Nakagawa, T., Mark, D.F., Takemura, K., Danhara, T., Suigetsu 2006 Project Members (2013): Identification and correlation of visible tephras in the Lake Suigetsu SG06 sedimentary archive, Japan: Chronostratigraphic markers for synchronising of east Asian/west Pacific palaeoclimatic records across the last 150 ka. Quaternary Science Reviews, 67, 121-137.

角田清美 (1975): 日本海および東シナ海沿岸の主な海 岸砂丘地带の形成期と固定期について. 第四紀研究,

14, 251-276. [Sumita, K. (1975): On the forming and fixing of sand dunes in some coastal dune regions along the Sea of Japan and the East China Sea in Holocene. Quaternary Research (DaiyonkiKenkyu), 14, 251-276. (in Japanese with English abstract) ]

角田清美 (1977): 喜界島，水天宮砂丘地内のクロスナ 層の ${ }^{14} \mathrm{C}$ 年代一日本の第四紀層の ${ }^{14} \mathrm{C}$ 年代 (117)地球科学, 31，134-135. [Sumita, K. (1977): ${ }^{14} \mathrm{C}$ ages of humic soils in Suitengu sand dunes, Kikaijima $-{ }^{14} \mathrm{C}$ age of the Quaternary deposits in Japan (117) - . Earth Science (Chikyu Kagaku), 31, 134135. (in Japanese)*]

澄田直敏・堂込秀人・池畑耕一 (2003) : 喜界町総合グ ラウンド遺跡 (弓道場) 出土の土器. 鹿児島考古, 37, 25-32. [Sumita, N., Dogome, H. and Ikehata, K. (2003): Earthenwares excavated at the archeological remains in the General Ground of Kikai Town. Archeology of Kagoshima, 37, 25-32. (in Japanese)*]

高橋秀一・和田秀樹 (1998): 静岡大学 ${ }^{14} \mathrm{C}$ 年代デー 夕集 2. 静岡大学地球科学研究報告, 25, 19-29.

[Takahashi, S. and Wada, H. (1998): Radiocarbon age determination at Shizuoka University (2). Geoscience Reports of Shizuoka University, 25, 1929. (in Japanese with English abstract) ]

高橋秀一・和田秀樹・青木 浩 - 中村俊夫 (1998)：鹿 児島県喜界島陸産貝類の ${ }^{14} \mathrm{C}$ 濃度以上について. 名古 屋大学加速器質量分析計業績報告書, 9, 201-211.

[Takahashi, S., Wada, H., Aoki, H. and Nakamura, T. (1998): ${ }^{14} \mathrm{C}$ concentration anomaly of land-snail for ${ }^{14} \mathrm{C}$ age determination in Kikai Island, Kagoshima Prefecture, southwest Japan. Summaries of Researches Using AMS at Nagoya University, 9, 201-211. (in Japanese with English abstract)]

武永健一郎 (1968): 喜界島の地形・地質. 奄美群島 自然公園予定地基本調査書，鹿児島県，263-300.

[Takenaga, K. (1968): Landforms and geology of Kikaijima. Fundamental Reports on the District Planned Sites for Natural Park of Amami Islands (Amami Gunto Shizen Koen Yoteichi Kihon Chosasho), Kagoshima Prefecture, 263-300. (in Japanese)*]

Tamura, T., Kodama, Y., Bateman, M.D., Saitoh, Y., Watanabe, K., Matsumoto, D. and Yamaguchi, N. 
(2001): Coastal barrier dune construction during sea-level highstands in MIS 3 and 5a on Tottori coast-line, Japan. Palaeogeography, Palaeoclimatology, Palaeoecology, 308, 492-501.

Thompson, W.G., and Goldstein, S.L. (2006): A radiometric calibration of the SPECMAP timescale. Quaternary Science Reviews, 25, 3207-3215.

Wang, Y.J., Cheng, H., Edwards, R.L., An, Z.S., Wu, J.Y., Shen, C.C. and Dorale, J.A. (2001): A highresolution absolute-dated Late Pleistocene monsoon record from Hulu Cave, China. Science, 294, 2345-2348.

横尾正樹（2012）：琉球列島における縄文時代早期から
中期にかけての土器文化の展開. 南島考古， 31，1330. [Yokoo, M. (2012): Development of ceramic culture in the Ryukyus in Early Jomon to middle Jomon period. Nanto Koko, 31, 13-30. (in Japanese)*]

Yokoyama, Y., Kido, Y., Tada, R., Minami, I., Finkel, R.C. and Matsuzaki, H. (2007): Japan Sea oxygen isotope stratigraphy and global sea-level changes for the last 50,000 years recorded in sediment cores from the Oki Ridge. Palaeogeography, Palaeoclimatology, Palaeoecology, 247, 5-17.

* Title etc. translated by H.M. 